U.S. Coat Goard Ocearographic Roport

U N I T E D S T A T E S C O A S T G U A R D OCEANOGRAPHIC REPORT No. 36

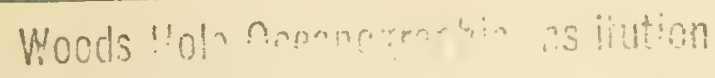

CG $373-36$

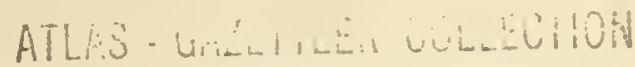

THE SIGNIFICANCE OF COLOR BANDING IN THE UPPER LAYERS OF KARA SEA SEDIMENTS

6

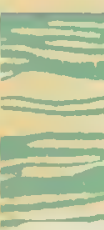

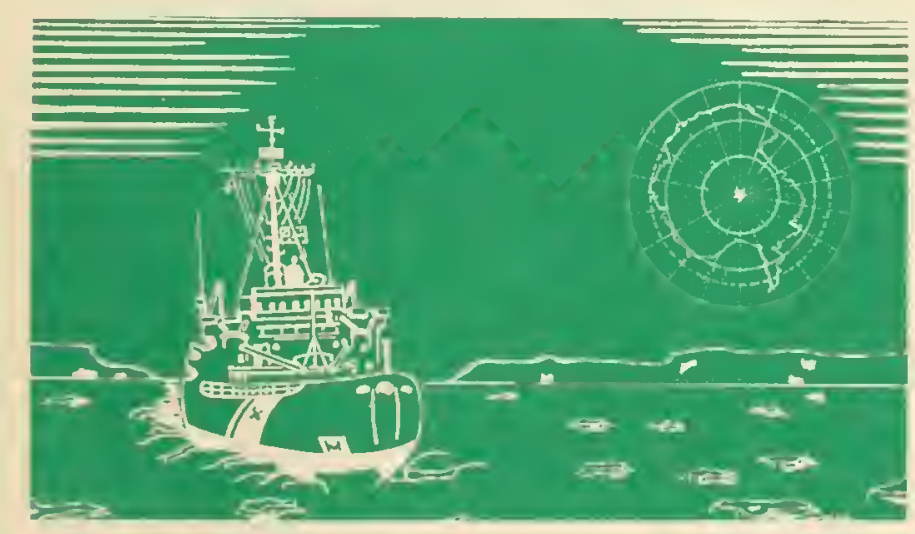

PLEA:

$\because$ STITUT!

Find
RN

LITRARY

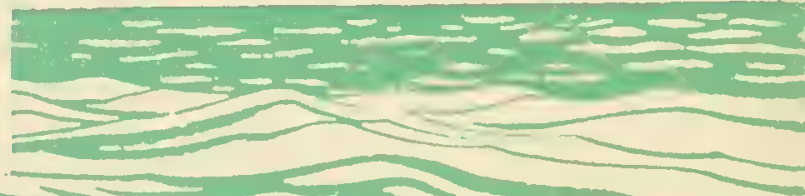

A3

no 36 
U N I T E D S T A T E S C O A S T G U A R D OCEANOGRAPHIC

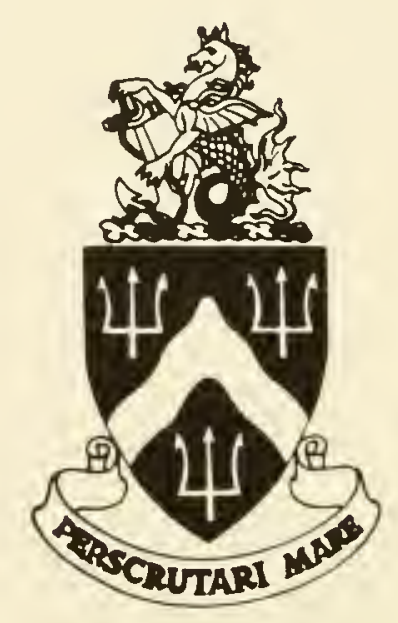

UNITED STATES COAST GUARD OCEANOGRAPHIC UNIT 


\section{REPORT No. $36_{\text {cg } 373-36}$}

\section{THE SIGNIFICANCE OF COLOR BANDING}

IN THE UPPER LAYERS OF KARA SEA SEDIMENTS

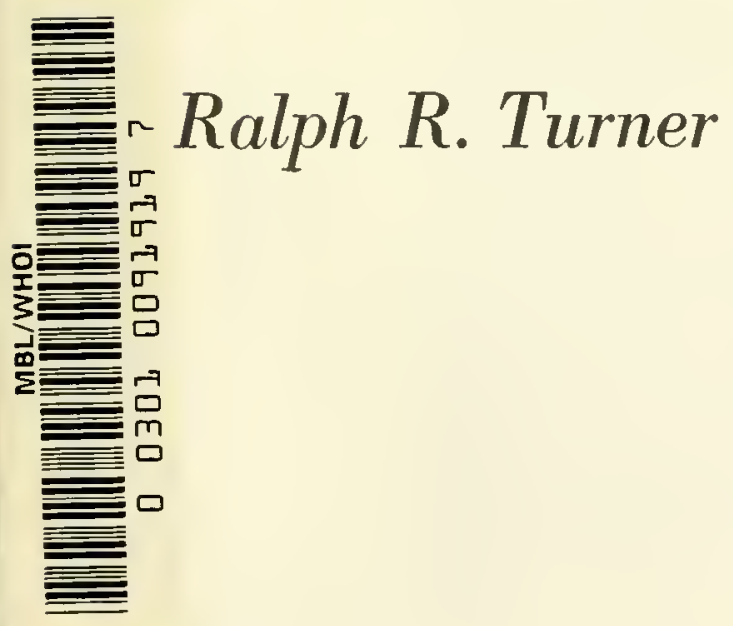

WASHINGTON, D.C. \$ 



\section{Abstract}

Sediment core samples from the deeper areas (>200 meters) of the Kara Sea, composed almost entirely of terrigenous clastics, are predominantly silty clay which is very poorly sorted, near-symmetrical to coarse-skewed and mesokurtic. The clay minerals are kaolinite, chlorite, illite, an expandable component which is probably montmorillonite, and possibly some mixed layer clays.

The upper layers in many cores display a color sequence from the surface downward of light brown to dark brown to yellowbrown to gray-green to brown to gray-green. No significant textural or mineralogical difference exists between brown layers and gray-green ones. In two cores non-detrital iron and manganese are greatly enriched in the brown surface layers but not at the same stratigraphic level. The highest concentration of non-detrital manganese occurs several centimeters nearer to the sediment-water interface than does the highest concentration of non-detrital iron. Beneath the surface layers the concentration of both elements is greatly reduced except in the secondary brown layers which are somewhat enriched in non-detrital iron and very slightly in non-detrital manganese.

Non-detrital material isolated from the upper manganeseand iron-enriched layers gave no diagnostic $\mathrm{X}$-ray diffraction patterns and is probably amorphous or crypto-crystalline. Coprolitic material from one secondary brown layer was identified as the iron phosphate, vivianite.

The concentration of non-detrital iron in 98 surface samples generally increases toward the mouths of the Siberian rivers, suggesting that these are the sources of iron in the Kara Sea. The distribution of non-detrital manganese in surface sediments apparently is controlled by factors other than distance from source. The non-detrital $\mathrm{Mn} / \mathrm{Fe}$ ratio generally increases away from the river mouths, suggesting that iron is deposited nearer the points of influx than manganese.

The distribution of non-detrital iron and manganese with depth in the cores appears to the controlled by post-depositional processes, including dissolution, migration, and subsequent differential oxidation of iron and manganese ions, rather than by primary depositional processes or variability in the rate of influx. 



\section{CONTENTS}

Title page

Abstract

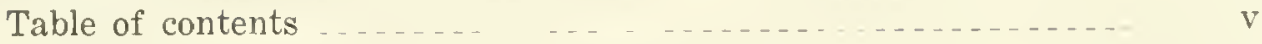

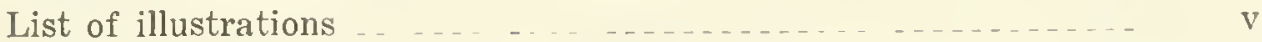

Introduction

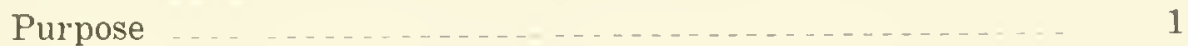

Location and physical characteristics _................ 1

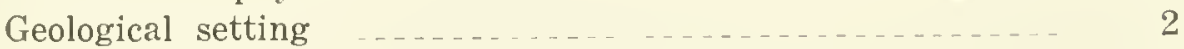

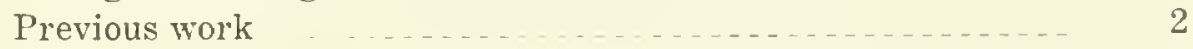

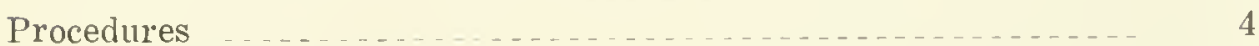

Field methods $\ldots \ldots \ldots \ldots$

Laboratory methods $\ldots \ldots \ldots \ldots$

Statistical methods . . . . . .

Results ... _ _.

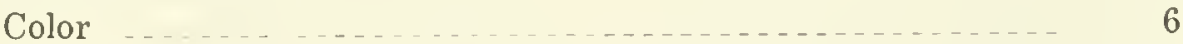

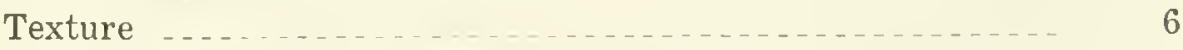

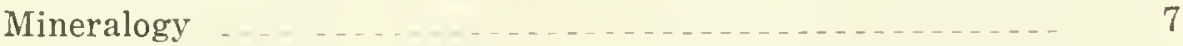

Vertical distribution of nondetrital iron and manganese _.... 7

Regional distribution of nondetrital iron and manganese _.. 7

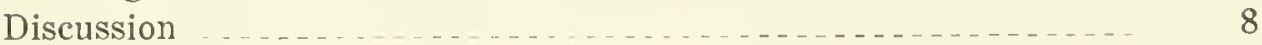

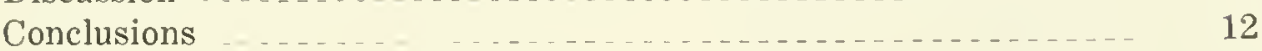

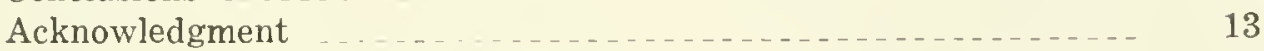

References _.......... 13

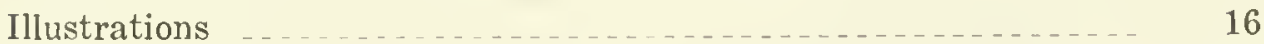

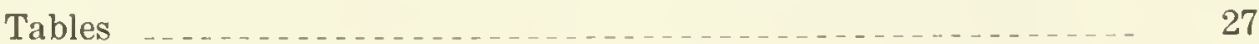

\section{Illustrations}

Figure Page

1. Physiography and circulation pattern of the Kara Sea _.... 16

2. Redox potential and $\mathrm{pH}$ in two KNIPOVICH cores from the Kara Sea _.......................... 17

3. Station locations and bathymetry 18

4. Color variations with depth in 10 cores from the
northern Kara Sea

5. Color variations and distribution of gravel, sand, silt and clay with depth in cores from stations E-8 and E-11 (Svyataya Anna Trough)

6. Color variations and distribution of gravel, sand, silt and clay with depth in cores from stations E-21, E-22, E-25, and E-26 (East Novava Zemlya Trough)

7. Color variations and distribution of gravel, sand, silt and clay with depth in cores from stations E-28, E-29, E-30, E-31 (East Novaya Zemlya Trough)

8. Distribution of nondetrital iron and manganese and color in core $\mathrm{E}-26$ and $\mathrm{N}-148$

9. Percent Nondetrital iron in surface sediments (Linear trend surface) 
10. Percent nondetrital manganese in surface sediments

(linear trend surface)
11. Nondetrital $\mathrm{Mn} / \mathrm{Fe}$ ratio in surface sediments

(linear trend surface)

\section{Tables}

Table

Page

1. Profile of a typical core from the Kara Sea

2. Percent of major clay groups and peak area ratios for cores E-26 and E-21

3. Means and standard deviations for nondetrital iron, manganese, and $\mathrm{Mn} / \mathrm{Fe}$ ratio in the surface sediments for each deeper extractable iron, manganese, and $\mathrm{Mn} / \mathrm{Fe}$ ratio in the surface sediments of the southwestern Kara Sea

4. Distribution of manganese and iron oxides in secondary microzonal profile of mud from Lake Valk-Yarvi ...........

5. Station positions and water depths for Northwind (1965) sediment samples

6. Station positions and water depths for Edisto-Eastwind (1967) sediment samples

7. Core descriptions (E-Series) _..................... 29

8. Gravel, sand, silt and clay percentages _._._._. 32

9. Textural parameters 32

10. X-ray diffraction data for black crusts from core E-26, 3-7 $\mathrm{cm}$ and for brown earthy material from core $\mathrm{E}-26,7-10 \mathrm{~cm}$

11. Comparison of X-ray data for pellets separated from core E-31, 20-23 cm, with data for the mineral vivianite

12. Distribution of nondetrital iron and manganese in core $\mathrm{E}-26$

13. Distribution of nondetrital iron and manganese in core $\mathrm{N}-148$

14. Nondetrital iron and manganese in surface sediments

15. HCI-extractable iron and manganese in surface sediments of southwestern Kara Sea 


\title{
THE SIGNIFICANCE OF COLOR BANDING IN THE UPPER LAYERS OF KARA SEA SEDIMENTS
}

\author{
Ralph R. Turner ${ }^{1}$
}

\section{Introduction}

\section{Purpose}

Geological investigations of much of the Kara Sea have been limited by inaccessibility to all but icebreakers and by diplomatic considerations because of its strategic position north of Western Siberia. In spite of these limitations, two reconnaissance surveys have been conducted by United States icebreakers (USCGC Northwind, 1965 ; USCGC Edisto and USCGC Eastwind, 1967). In compliance with the Continental Shelf Treaty of 1961 (signed by the United States in 1964), bottom sampling during these surveys was limited to water depths in excess of 200 meters. The present study was undertaken to evaluate the textural, mineralogical, and geochemical significance of remarkably similar color sequences displayed in the upper layers of sediment cores collected.

\section{Location and Physical Characteristics}

The Kara Sea is located on the Arctic Eurasian Continental Shelf between Zemlya Frantsa Iosifa and Severnaya Zemlya archipelagos and extends southward along the east coast of Novaya Zemlya to the Eurasian coast (fig. 1). It is the westernmost of the series of Arctic epicontinental marginal seas lying along the northern shores of Siberia.

The area of the Kara Sea is $883,000 \mathrm{~km}^{2}$ of which only $190,000 \mathrm{~km} .^{2}$ exceeds 200 meters in water depth. This deeper water is restricted to two north-facing reentrants, or troughs, in the northern part of the sea and to a $740-\mathrm{km}$. arcuate trough parallel to and convex towards Novaya Zemlya. The greatest depth (approximately $600 \mathrm{~m}$.) occurs in the western reentrant, Svyataya Anna Trough, at the northern extremity. The other two troughs, Voronin and
Novaya Zemlya, have depths up to $430 \mathrm{~m}$. (Northwind sounding). A glacial erosion origin has been suggested for all three troughs on the basis of their geomorphology and geographic location (Johnson and Milligan, 1967).

A striking physical feature of the Kara Sea is a well-developed deltaic system which extends some $300 \mathrm{~km}$. seaward of the river mouths in the southern part of the sea (Johnson and Milligan, 1967) Delta development in this region is not surprising considering the large annual discharge of suspended matter ( $30 \times 10^{6}$ tons, Kulikov, 1961) from the $\mathrm{Ob}$ and Yenisey Rivers which debouch into the Kara Sea from the south. The Central Kara Plateau which extends northward between the Svyataya Anna and Vorinin Troughs is not part of the deltaic system but is overlapped by it at $79^{\circ} \mathrm{N}$. (Johnson and Milligan, 1967). The two small islands, Vize and Ushakova, are on this plateau.

In spite of the summer stratification, the depths of the deeper troughs remain well ventilated. Data from Garcia (1969) showed values for dissolved oxygen during the summer no lower than $6.15 \mathrm{ml}$./Jiter for the deepest water samples from the East Novaya Zemlya Trough.

Water which originates in the Atlantic Ocean, called Atlantic water, $\left(\mathrm{T} \geq 0^{\circ} \mathrm{C}\right.$. $\mathrm{S} \geq 34 \%$ ) also enters the Kara Sea via several pathways. Off the northern tip of Novaya Zemlya, Atlantic Water which has transited the Barents Sea continues westward into the Kara Sea where it largely mixes with both the continental runoff and Arctic water $\left(\mathrm{T}<-1.5^{\circ}\right.$ C., $\mathrm{S}=33.5$ to $34.5 \%$; Milligan, 1969 ). Atlantic water, considerably midified by transit along the continental slope north of Spitsbergen and Zemlya Frantsa Iosifa, also enters the 
Kara Sea through the St. Anna and Voronin Troughs. According to Milligan (1969) this subsurface flow is a counterflow to the northward flowing continental runoff. A trivial amount of Atlantic water also penetrates the Karaa Sea through the straits between Novaya Zemlya and the Siberian mainland (Zenkevitch, 1963; Milligan, 1969).

Other water masses present in the Kara Sea include Arctic water, which is probably formed by mixing of the continental runoff and Atlantic water, and Arctic bottom water $\left(\mathrm{T} \leq 0^{\circ} \mathrm{C}\right.$., $\mathrm{S} \geq 34.0^{\circ} \%$ ) which enters the deepest depth of the Svyataya Anna and Voronin Troughs as a compensatory flow to the outflowing continental runoff (Milligan, 1969).

Sea ice begins to form in the Kara Sea as early as September and melting starts only in June but ice cover even in midwinter is not solid or continuous (Zenkevitch, 1963). The ice that is formed off the Siberian coast and in the rivers, and icebergs calved from the relict glaciers on the north island of Novaya Zemlya, are carried by the cyclonic surface circulation into the lee of Novaya Zemlya, where they persist even into the summer (Nordenskjold and Mecking, 1928).

\section{Geological Setting}

The Kara Sea is situated amid rocks from nearly every geologic period. Precambrain shield, consisting mostly of gneisses and schists, is exposed on the northern shore of Taymyr Peninsula, the southwestern part of Severnaya Zemlya archipelago and several offshore islands (Rabkin and Ravich, 1961). Slightly metamorphosed and folded Paleozoic rocks, predominantly carbonates and clastics, compose Novaya Zemlya, the western islands of Severmaya Zemly archipelago and much of the Yugorskiy Peninsula (Markov and Tkachenko. 1961). Mesozioc deposits occupy Zemlya Frantsa Iosifa and the islands Ushakova and Vize and consist mostly of friable clastics with considerable organic remains including coal (Dibner, 1957). The region between Yugorskiy and Taymyr Peninsulas, termed the West Siberian Lowlands, is blanketed by a thick cover of unconsolidated Quaternary deposits (Saks, 1948).

The tectonics of the Kara Sea are complex and not completely worked out, but several de- tails are clear. Novaya Zemlya and Vaigach Island, which lies between Novaya Zemlya and the Soviet mainland, are a tectonic continuation of a mainland axis which branches off laterally from the northern end of the Urals (Nordenskjold and Mecking, 1928). Tectonic trends also connect the northern border of Taymyr and the Severnaya Zemlya archipelago (Nalivkin, 1960) and are probably connected with the Ural trend.

Many of the islands and the floor of the Kara Sea are marked by numerous abrasional terraces which reflect the complex glacial and postglacial history of this region. Novaya Zemlya and the Taymyr-Severnaya Zemlya region were principal centers of glaciation which progressed over a considerable part of the Russian plain (Saks, 1948; Saks and Strelkov, 1961). Saks (1948) concluded that tectonic pulsations in the northern part of Eurasia during the Quaternary rather than eustatic and isostatic factors were largely responsible for the oscillations in the coastal contours. Nonetheless the beds of the $\mathrm{Ob}$ and Yenisey Rivers can be traced to a depth of 100 meters in the Kara Sea (Saks, 1948) and there are many deltaic channels within a 35 to 70 meter depth range on the continental shelf which Johnson and Milligan (1967) favored as being relicts of a lower sea level. The shore structure of Novaya Zemlya, on the other hand, is defined by ascending vertical movements (Zenkovitch, Leontiev, and Nevessky, 1960) and the rivers of Western Siberia appear to be "entrenched" lather than "drowned" (Lazukov, 1964). The conflicting evidence of sea level fluctuations in the Kara Sea has been reviewed and illustrated by Lazukov (1964, see esp. fig. 1).

\section{Previous Work}

Klenova (1936) first outlined the general sediment distribution in the southwestern Kara Set. She observed that the sediments in all the deeper areas were predominantly silty clay or mud (over 50 percent less than 0.01 $\mathrm{mm}$.) and terrigenous silt of glacial marine origin and were brown in color in the upper layers. She also noted that the sediment texture tended to reflect the cyclonic rotation of surface water in the southwestern part of the Kara Sea which permitted mud to accumulate in quite shallow water. 
Klenova (1938) suggested that iron and manganese oxides were responsible for the brown color in the upper layers of Kara Sea sediments and that the stability of these oxides, and hence the color of the sediments, was dependent on the amount of dissolved oxygen in bottom and sediment interstitial waters and organic matter in the sediments.

Brujevicz (1938a,b) and Trofimov (1939) measured the redox potential (Eh) and $\mathrm{pH}$ with depth in several Kara Sea cores. Trofimov (1939) observed a transition from oxidizing to reducing conditions on entering subsurface gray-green layers and a corresponding sharp decrease in the $\mathrm{pH}$ at the boundary between oxidizing and reducing conditions (fig. 2). $\mathrm{He}$ proposed that isolation of strata from oxygenated bottom waters by burial and consumption of oxygen in interstitial water by oxidation of organic matter produced the redox potential and $\mathrm{PH}$ profiles. The sharp decrease in $\mathrm{pH}$ at the boundary between oxidizing and reducing conditions was attributed to hindered removal of the $\mathrm{CO}_{2}$ produced in the oxidation of organic matter. Brujevicz $(1938 a, b)$ predicted a separation of the more mobile phases of iron and manganese in response to the gradient in redox potential between buried strata and the sediment-water interface.

Klenova and Pakhomova (1940) observed an increase in the content of manganese with decreasing grain size in Kara Sea sediments, with clayey muds averaging 1.2 percent by weight manganese. They also noted that the highest content of manganese ( 3.5 percent) occurred in dark brown (chocolate) sediments and these occurred in regions where the salinity gradient between surface and bottom water was the greatest.

Yermolayev $(1948 a, b)$ has characterized the typical physical features of Recent Kara Sea stratigraphy (table 1 ). He proposed that nonuniform lithogenetic processes associated with microorganisms and the hydrological regime have operated to produce the physical and chemical properties observed in Kara Sea cores. The processes are nonuniform according to Yermolayev because aerobic conditions prevail in some layers (upper brown) and anaerobic conditions prevail in others (subsurface gray-green) and because the hydrology of the Kara Sea has undergone changes in the recent geologic past in response to periodic influx of warm Atlantic waters at intermediate depths. He observed a direct correlation between the thickness of the warm intermediate Atlantic water and the thickness of oxidized (brown) bottom sediments in the Arctic seas and polar basin and suggested that the secondary (buried) brown layers were generated during periods of maximum influx of Atlantic water. According to Yermolayev these periods would be characterized by well ventilated bottom waters in response to the increased surface and intermediate circulation which would favor oxidation and retention of ferromanganese compounds in the sediments. The finding by Belov and Lapina (1959) of increased amounts of ferric and manganese oxides in Arctic basin sediments deposited during periods of influx of warm Atlantic waters into the Arctic Ocean lends some support to Yermolayev's hypothesis.

The results of an experiment conducted by Yermolayev $(1948 a, b)$ shed considerable light on the nature of the stability of the secondary brown layers and the reversibility of aerobicanaerobic processes. When a typical core (table 1) from the Kara Sea was inverted, i.e., placed such that the brown layers $(1 a, 1 b, 1 c)$ were sealed off from exchange with overlying water and the gray-green layers exposed to exchange with the overlying water, the brown layers were transformed to gray-green layers and the gray-green layers transformed to brown layers after a period of 17 months. The exception to this was that the bright orange layer ( $1 c$ ) did not transform. This layer and the lower brown layer (11b) were designated "zones of lithogenesis" by Yermolayev and possessed the highest $\mathrm{Fe}^{3+} / \mathrm{Fe}^{2+}$ ratio $(20-$ 25). He demonstrated that bacteria were largely responsible for this transformation by repeating the experiment with sterilized sediment. In this case the transformation was considerably retarded, if not halted completely. He concluded that bacteria played a considerable role, even if indirect, in determining the physical characteristics of Kara Sea sediments.

Gorshkova (1957) outlined in detail the textural, mineralogical and geochemical characteristics of Kara Sea sediments both regionally and with depth in cores. She also concluded that the color of Kara Sea sediments depended 
largely on their ferromanganese content and demonstrated that sediment color and benthic biomass were closely related.

Gorshkova (1966) suggested that the large accumulations of manganise in Kara Sea sediments were attributable to the semiclosed configuration of the coastal zone of the Kara Sea which, coupled with the great quantity of manganese brought in by the inflowing rivers favored the vital activities of microorganisms and the biochemical settling of manganese.

Nesterova (1960) investiagted the chemical composition of the suspended and dissolved loads of the Ob River which enters the Kara Sea from the south and found that Fe, Mn, P and other minor elements are transported largely in mechanical suspension and only partly in solution.

Strakhov (1966, using the data of Nerterova (1960) for the chemical composition of Ob River water and the data of Gorshkova (1957) for the composition of Kara Sea sediments, found more iron and manganese in the surface sediments of the Kara Sea than could be accounted for by river input alone. He attributed the excess to the migration of iron and manganese from the reducing zone of gray and graygreen sediment layers to the oxidizing zone of the brown upper layers.

Kulikov (1961) observed that the highest iron and manganese concentrations were in clayey sediments and in areas of the Kara Sea where $\mathrm{Ob}$ and Yenisey river water is found. $\mathrm{He}$ also noted a tendency for iron and manganese to concentrate in trough and depression sediments.

Kulikov (1961) reported that in the Kara Sea the mineralogical composition varies relatively little with depth in sediment cores. Heavy minerals may constitute as much as 10 percent of the 50 to 100 micron fraction (Gorshkova, 1957; Kulikov, 1961). According to Kulikov, amphibole, pyroxene, epidote and dark ore minerals in varying proportions make up the bulk of the heavy fractions. The light fractions contain predominantly quartz (60 to 80 percent), orthoclase ( 20 to 30 percent, sometimes 40 to 60 percent), and plagioclase ( 5 to 20 percent). The clay fractions contain up to 70 percent hydromica.

Estimates of rates of sedimentation for the deeper areas of the Kara Sea based on both radium concentrations and clastic inputs to the Kara Sea (Yermolayev, 1948a,b; Saks, 1953, cited in Kulikov, 1961) range from 4 to $6 \mathrm{~cm}$. per thousand years. The rate of sedimentation within the boundaries of the Ob-Yenisey shallows $(<50 \mathrm{~m}$.) varies from 30 to $100 \mathrm{~cm}$. per thousand years (Saks, 1953, cited in Kulikov, 1961).

\section{Procedures}

\section{Field}

The cores from the CGC Northwind survey from which surface samples were cut for this study were obtained with a Kullenberg gravity corer. The cores from the CGC Edisto-CGC Eastwind survey (fig. 3) were obtained with a Phleger corer. Cores from both surveys were retained in plastic liners and were stored at low temperature (above freezing) to reduce bacterial activity. Sediment samples remaining after the analyses described below are available on request from the author at the Department of Oceanography, Florida State University, Tallahassee, Fla. 32306, and after August, 1971, from the Smithsonian Oceanographic Sorting Center, Washington, D.C. 20390 .

\section{Laboratory}

In the laboratory the cores were split longitudinally, described (table 7) and sampled. Surface samples from 42 Northwind cores and 5 grab samples were obtained from the University of Wisconsin, Geophysical and Polar Research Center, and were used for the geochemical analyses. In addition core $\mathrm{N}-148$ was sampled at $1-\mathrm{cm}$. intervals for the geochemical sampled at $10-\mathrm{cm} ., 5-\mathrm{cm}$, or shorter intervals for grain size analyses and at $1-\mathrm{cm}$ intervals for the geochemical analyses. With the exception of core E-26 which was studied in detail, only the top centimeter of each core was used for the geochemical studies.

The samples cut from the CGC Edisto-CGC Eastwind survey cores for grain size analyses 
averaged 5 to 15 grams dry weight and were. sized using standard sieving and pipette procedures (Folk, 1965). Grain size analyses on the CGC Northwind cores have been conducted by the U.S. Naval Oceanographic Office (Andrew and Kravitz, 1968).

Because 71 of 88 samples (Edisto-Eastwind) analyzed for grain size distribution contained more than 90 percent clay-and silt-sized material with the larger proportion being clay-sized, X-ray examination of the clay-sized ( $<4$ microns) was more appropriate than optical studies of the coarse (sand-sized) fractions ( $>62$ microns). In addition, preliminary analyses revealed that heavy minerals (S.G. greater than 2.95) made up only about 1 percent of the 62-250 micron fraction in eight surface samples from the East Novaya Zemlya Trough. Thus coarse fraction mineralogy of sediments from the deeper troughs may not be truly representative of the total sediment mineralogy.

Samples from both brown and gray-green layers were selected from cores $\mathrm{E}-21$ and $\mathrm{E}-26$ for the clay mineralogy studies. The clay-sized fraction was separated by settling and oriented slides were prepared by air-drying aliquots on glass slides. The error in quantitative determinations introduced by this mounting technique (Gibbs, 1965) renders the results reported here at best semiquantitative. The slides were $\mathrm{X}$-rayed using Ni-filtered Cuka radiation from $2^{\circ}$ to $30^{\circ} 2 \theta$. Each slide was X-rayed again after treatment with ethylene glycol to reveal expandable components. No attempt was made to distinguish chlorite from koalinite although both were present in all samples as evidenced by a broad, often double peak at 3.53 to $3.57 \AA$. Peak areas for the basal (001) reflections were measured and used to make semiquantitative estimates of the proportions of montmorillonite, chlorite/kaolinite and illite in each sample.

Selected fragments from several of the coarse fractions ( $>62$ microns) were also pulverized and X-rayed using a Debye-Scherrer powder camera. $\mathrm{Zn}$-filtered Moka radiation was used in some instances to reduce fluorescence of ferromanganese compounds in the samples.

The 67 surface and 53 subsurface samples selected for geochemical analyses were air-dried and ground in a porcelain mortar to pass an 80 - mesh sieve. Of each sample, $100 \mathrm{mg}$. were then treated for about 4 hours with $10 \mathrm{ml}$. of a solution equivalent to $1 \mathrm{M}$-hydroxylamine hydrochloride and 25 percent $(\mathrm{V} / \mathrm{V})$ acetic acid. The details and an evaluation of this procedure are given by Chester and Hughes (1967). This treatment dissolves most of the ferromanganese minerals, the carbonate minerals and extracts adsorbed trace metals, but does not affect detrital minerals (Chester and Hughes, 1967), other than detrital carbonates. After dilution of the solutions resulting from the above treatment, suitable aliquots were analyzed for iron and manganese using atomic absorption (Beckman Model 1301 coupled to a DB-G Spectrophotometer). Standard solutions were prepared in a dilute $\mathrm{HCl}$ matrix and sample matrix effects checked by standard additions. Duplicate and triplicate analyses of selected samples established that the analytical precision was always within \pm 10 percent and frequently within \pm 5 percent.

Several samples were also analyzed for total iron and manganese. After fusing with $\mathrm{LiBO}_{2}$ (Shapiro, 1967) the whole sediment was dissolved in weak $\mathrm{HCl}$ and analyzed for iron and manganese using the same standards employed for the nondetrital extractions. Matrix effects were present in the total iron and manganese analyses and the resulting values could only be considered semiquantitative. The concentrations obtained for extractable (nondetrital) and total manganese were similar, indicating that manganese is almost entirely associated with the nondetrital fraction. The total iron content, however, was three to four times higher than that found in the nondetrital extraction. This is in agreement with the findings of Chester and Hughes $(1966,1967,1969)$ and suggests that iron is largely in the silicate or resistant oxide phases.

\section{Statistical}

The data of the sedimentary properties such as percent gravel, sand, silt, clay and mean grain size, standard deviation, skewness and kurtosis were computed by digital computer based on the results of the grain size analyses. The geochemical data for the surface samples were submitted to a series of linear multiple regression analyses using the computer. Miller (1956) and Krumbein (1959) have discussed 
the importance of similar analyses for the purpose of data "smoothing" and interpretation.

Because of inequable sample spacing the geochemical ciata were divided into three geographic groupings, the East Novaya Zemlya Trough $(N=15)$, the St. Anna Trough $(N=39)$ and the Voronin Trough $(N=13)$. Three-dimensional regression surfaces were developed for each of the three data groupings and for selected combinations of the groupings by using the expression $Z=f(x, y)^{x}$, where $x$ and $y$, the geographic coordinates of a sample location measured from an arbitrary origin, are the independent variables, and each geochemical attribute $(z)$ is the dependent variable. The independent variables are raised to higher and higher polynomials, with the coefficients of the polynomials being determined through standard mairix techniques on the digital computer using least squares analysis. A statistical analysis of variance was used to select the polynomial which accounted for the largest significant reduction in the variability of the data (Goodell, 1967). For this study no polynomial higher than linear proved to be significant at the 95 percent confidence level.

\section{Results}

\section{Color}

The color variations with depth in the 20 cores from the Edisto-Eastwind collection are given in figures 4-7. Although no two cores show exactly the same variations, there are marked similarities, especially in the upper 10 to $15 \mathrm{~cm}$. With the exception of core E-32 which is greenish-gray throughout, every core is some shade of brown in the upper layers and grades sharply or gradually into gray or green lower layers. Several of the Edisto-Eastwind cores (table 7, e.g., E-8, 20 to $38.5 \mathrm{~cm}$.) show gray-green layers which are mottled by black lumpy material similar to the substance described by Klenova (1948, cited in Strakhov, 1966) and identified as hydrotroilite (FeS n $\mathrm{H}_{2} \mathrm{O}$ ).

The generalized color sequence (table 1) given by Yermolayev $(1948 a, b)$, brown to dark brown to bright orange (brittle) to gray to brown (brittle) is best represented in cores E-8, E-12, E-18, E-25, E-26, E-31, E-34, and $\mathrm{E}-35$. The rest have layers which can be identified with one of Yermolayev's layer's but the sequence is incomplete or out of order.

The cores from the Northwind collection also show similar color variations with depth (Andrew, personal communication) and many display the generalized color sequence of Yermolayev (table 1 and fig. 8, for typical sequences).

\section{Texture}

The distribution of gravel, sand, silt and clay with depth in the eight cores from the No- vaya Zemlya Trough and two cores from the Svyataya Anna Trough is given in figures 5-7. Almost without exception the cores consist of silty clay (classification after Shepard, 1954) throughout. The exceptions are core E-28 which contains appreciable sand and gravel in the lower layer and core $\mathbf{E}-21$ which has sandy layers.

The 10 cores (fig. 4) not analyzed below the surface layer for grain size distribution likewise consist of silty clay in the surface layers except for cores E-14 and E-15 which contain considelable sand and some gravel (app., table 8 ). There is no visible evidence table 7) of marked shifts in the proportions of sand, silt and clay below the surface layers of these cores.

The statistical parameters (table 9) support the observation of little variability in the grain size distribution with depth in the cores. Almost without exception the mean size of the sediments corresponds with very fine silt to clay on the Wentworth size scale and the sediments are very poorly sorted, near-symmetrical to coarse-skewed and mesokurtic. The few departures from these characteristics are also reflected in the distribution of gravel, sand, silt and clay (figs. 5-7).

The percentages of each size fraction show a marked increase in the amount of material finer than 1.0 micron below the surface layers. The quantity of this material increased from ca. 30 percent in the surface layers to ca. 40 percent on entering the subsurface gray-green layers and did not decrease again on entering secondary brown layers. Only where the per- 
centage of sand-sized material increased significantly over the mean for the whole core, as in core E-21, 22 to $36 \mathrm{~cm}$. and 39 to $42 \mathrm{~cm}$. and $\mathrm{E}-28,20$ to $28 \mathrm{~cm}$., did the percentage of material finer than 1.0 micron decrease again in subsurface layers.

\section{Mineralogy}

The chief clay-sized minerals which were found in the samples examined by $\mathrm{X}$-ray diffraction consisted of illite, chlorite, kaolinite, and an expandable component which is probably montmorillonite. The percentages of each clay group (table 2) revealed moderate variability with depth in the cores examined, with the greatest differences existing between the surface $(0$ to $3 \mathrm{~cm}$.) and lower layers.

The percentages of chlorite-kaolinite ranged from 21 to 32 percent in core E-26 and from 13 to 32 percent in core $\mathrm{E}-21$, with the highest percentage occurring in the surface layers of both cores. The percentages of illite ranged from 33 to 50 percent in core E-26 and from 32 to 44 percent in core E-21 with the highest percentages in the lowest and surface layers respectively. In core $\mathrm{E}-26$ the surface layer contained the second highest value of illite ( 48 percent). The percentages of montmorillonite ranged from 20 to 42 percent in core $E-26$ and from 24 to 53 percent in core E-21 with the lowest percentages occurring in the surface samples.

The peak area ratios (table 2 ), chloritekaolinite/illite and montmorillonite/illite, range from 0.43 to 0.74 and 0.41 to 1.27 respectively in core E-26 and from 0.39 to 0.72 and 0.53 to 1.55 respectively in core $\mathrm{E}-21$. In core E-26 the montmorillonite/illite ratio shows an increase with depth in the core in the upper brown layers followed by a sharp decrease on entering the upper gray layer. This ratio increases again in the secondary brown layer and adjacent layers in core E-26. The peak area ratios for core $\mathrm{E}-21$ support the observation of an increasing montmorillonite/illite ratio with depth in the upper brown layers but reveal no increase in the montmorillonite/illite ratio in secondary brown layers.

Microscopic examination of the coarse fractions from the upper layers of core E-26 revealed minor amounts of black crusty material in the layer 3 to $7 \mathrm{~cm}$. from the surface and light brown earthy material in the layer 7 to $10 \mathrm{~cm}$. from the surface. X-ray diffraction patterns (table 10) of these substances revealed a number of peaks which could not be attributed to any of the common detrital minerals and which did not seem to fit any of the published diffraction pattel'ns of iron and manganese minerals. Many of the unidentified peaks were broad and diffuse, suggesting small particle size and/or poor crystallinity.

Examination of the coarse fractions from other brown layers in core E-26 and in other cores revealed physically similar substances to those X-rayed but never in abundance except for core E-31 which contained abundant coprolitic matter in a secondary brown layer (20 to $23 \mathrm{~cm}$.). X-ray study of this substance (table 11) proved it to be the iron phosphate, vivianite. Andrew (personal communication) also reported an occurrence of vivianite in a secondary brown layer in core N-77 (fig 3 ).

\section{Vertical distribution of nondetrital iron and manganese}

The vertical distribution of iron and manganese and sediment color in cores E-26 and $\mathrm{N}-148$ is compared in figure 8. Manganese and iron are enriched in separate bands somewhat below the sediment-water interface in dark brown and yellowish-brown or reddish-brown layers respectively. Iron, and to some slight extent manganese, are also concentrated in subsurface brown layers but the enrichment here of both elements is not nearly so pronounced as in the near-surface layers. The $\mathrm{Mn} / \mathrm{Fe}$ ratio (tables 12 and 13) is not constant but varies from 5.54 at 3 to $4 \mathrm{~cm}$. to 0.03 at 8 to $9 \mathrm{~cm}$. in core E-26 and from 1.40 at 5 to $6 \mathrm{~cm}$. to 0.01 at 43.5 to $44.5 \mathrm{~cm}$. in core $\mathrm{N}-148$. The particularly high value for manganese (6.20 percent) at 3 to $4 \mathrm{~cm}$. in core $\mathrm{E}-26$ is notable because the value is higher than is usually observed, even in total sediment analysis. A secondary peak is observed on the shoulder of the major manganese peak in both cores.

\section{Regional distribution of nondetrital iron and manganese}

In the surface sediments of the Kara Sea the concentration of nondetrital iron varies between 0.43 and 3.04 percent, the concentration 
of nondetrital manganese varies between 0.01 and 2.62 percent, and nondetrital $\mathrm{Mn} / \mathrm{Fe}$ ratio varies between 0.02 and 2.15 (table 14). The mean values for iron, manganese and $\mathrm{Mn} / \mathrm{Fe}$ ratio are highest in the East Novaya Zemlya Trough and lowest in the Voronin Trough, with the Svyataya Anna Trough having values more similar to the Voronin than to the East Novaya Zemlya Trough (table 3 ). All values show a high degree of variability within a trough but iron shows the least variability (table 3).

The data for the East Novaya Zemlya Trough are subdivided because the E-series samples represent the top centimeter of each sediment core and the $\mathrm{N}$-series represent stratigraphic channel samples encompassing as much as $15 \mathrm{~cm}$. of the top of a core. The significance of the difference in these two sets of samples is related to the distribution of iron and manganese with depth in the cores (fig. 8). Surface samples which include more than the upper centimeter or two of sediment may include iron and manganese from layers just below the surface which are greatly enriched in these elements.

The data from Gorshkova (1957) for the southwestern Kara Sea (tables 3 and 14) which include several samples from the East Novaya Zemlya Trough and which represent samples from a wide range of water depths, tend to support the earlier suggestion that the reagents used in the present study extract only a small part of the total iron but almost all of the total manganese.

The regression analyses of the geochemical data revealed no significant (at the 95 percent confidence level) surfaces higher than linear. Thus it is possible to express a trend as a compass direction with the dependent variable in- creasing in that direction.

The content of nondetrital iron in surface sediments from the East Novaya Zemlya and Svyataya Anna Troughs increases towards the southeast $\left(128^{\circ}\right.$ to $\left.131^{\circ}\right)$. In the Voronin Trough, nondetrital iron increases towards the south $\left(192^{\circ}\right)$. The residuals do not appear to have any geological significance (fig. 9).

The similar trends observed for nondetrital iron in each trough are not observed for nondetrital manganese (fig. 10). Each trough displays a distinctly different trend direction. Manganese increases towards the coast of Novaya Zemlya $\left(287^{\circ}\right.$ ) in the East Novaya Zemlya Trough, towards the south $\left(186^{\circ}\right)$ in the Voronin Trough and towards the Central Kara Plateau $\left(95^{\circ}\right)$ in the St. Anna Trough. The residuals reveal a large area in the central St. Anna Trough which has a higher content of nondetrital manganese than the surface would predict. The positive residuals which appear in the East Novaya Zemlya Trough probably reflect the sampling procedure used for the seven Northwind cores from this trough, i.e., stratigraphic channel sampling instead of the "spot" sampling used for all other cores, rather than any natural phenomenon.

The nondetrital $\mathrm{Mn} / \mathrm{Fe}$ ratio (fig. 11) increases northward $\left(18^{\circ}\right)$ and northeastward $\left(45^{\circ}\right)$ towards the Arctic Ocean in the Svyataya Anna and Voronin Troughs respectively, but increases westwards $\left(288^{\circ}\right)$ towards Novaya Zemlya in the East Novaya Zemlya Trough. The residuals suggest that the $\mathrm{Mn} / \mathrm{Fe}$ ratio is higher in the central parts of all three troughs than the linear surface would predict. No geological significance can be attached to the latter observation for the East Novaya Zemlya Trough because of the sampling discrepancy outlined previously.

\section{Discussion}

Although color is one of the most readily observed mass characteristics of a sediment it is also one of the more difficult to evaluate. The color of naturally moist sediments under similar lighting conditions depends upon (1) the intrinsic color of detrital minerals of which each sediment is composed, (2) the size and packing of these minerals, (3) the amount and kind of organic matter, including skeletal material, and (4) the color and amount of any nondetrital constituents such as oxide coatings, cement and concretions (Weller, 1960; Krumbein and Sloss, 1963). Any interpretation of sedimentary color must therefore consider the contribution of each of these factors to the total mass effect of color. 
The detrital mineralogical observations of the present study do not reflect any significant changes in the clay mineralogy (table 2) or any readily apparent change in the detrital components of the coarse fractions across the upper layers of Kara Sea sediments. The observed downward increase in montmorillonite/ illite ratio across the upper brown layers and in the vicinity of the secondary brown layers in core E-26 would not contribute to the brown color of these layers because neither montmorillonite nor illite are brown clay minerals (Keller, 1953). The possibility exists that a mixed layer clay incorporating an expandable mineral and iron hydroxide (Rich, 1968) has formed in the Fe-rich layers but the evidence for this is weak.

The effects of particle size and size distribution can also be eliminated as responsible for the color variations in the upper layers of Kara Sea sediments because there are no marked textural changes across the upper layers (figs. 5-7). The decrease in fine clay content in the upper layers is probably related to authigenic cementation in this fraction by the high content of nondetrital ferromanganese oxides (fig. 8) and not to any real difference in the grain size distributions between surface layers and lower layers. Although particle packing increases with depth in sediments under natural compaction, in view of other factors to be discussed subsequently, packing does not appear to be significant in determining color in the upper layers of Kara Sea sediments.

In the Kara Sea the nondetrital sedimentary constituents, the stabilities of which depend upon the sufficiency or insufficiency of oxygen, and low abundance of aquatic life, would appear to exert the greatest influence on sedimentary color. Nondetrital iron and manganese compounds in varying proportions are the constituents of Kara Sea sediments which impart the brown color to the upper layers (Klenova, 1938; Brujevicz, 1938a,b; Trofimov, 1939; Klenova and Pakhomova, 1940; Yermolayev, $1948 a, b$; Gorshkova, 1957; figs. 5-7, this study). The sediment assumes a gray-green color typical of illite, chlorite and other clay minerals (Keller, 1953) when nondetrital iron and manganese are least abundant (fig. 8) and after mild acid leaching. That the brown color is nondetrital is also evidenced by the brown coatings on detrital mineral grains in the coarse fractions from brown layer's.

Any interpretation of the distribution of nondetrital iron and manganese in Kara Sea sediments must consider (1) the possible sources of iron and manganese, (2) the possibility of variability in the rates of influx and primary deposition of iron and manganese, and (3) the postdepositional mechanisms which could concentrate iron and manganese in some layers and not others in the absence of any variability in the rates of influx or primary deposition.

The trend analyses of the distribution of nondetrital iron and manganese in surface sediments (figs. 9, 10 and 11) are an attempt to locate the source(s) or point(s) of influx of these elements into the Kara Sea. Such an application of trend analyses assumes that nondetrital elemental concentrations will increase towards the source(s) or point $(s)$ of influx, when account is taken of dilution by detrital constituents. In the present study dilution effects are minimized by sampling within a comparatively narrow water depth range (200 to 600 meters), by small sample-to-sample variability in grain size distribution (app., tables 10 and 11; Andrew, in preparation), and by analyzing specifically for the nondetrital component of the total iron and manganese content.

The observation of a regional increase in the concentration of nondetrital iron in surface sediments toward the Siberian mainland (southward) is consistent with a possible source for this element in the Siberian rivers. In order for the concentration of a nondetrital component to show a relative increase in the direction of a detrital source there must also be an increase in the absolute quantity of the nondetrital component to compensate for detrital dilution in the direction of the source. The spread of continental runoff across the Kara Sea from the river mouths to north of $80^{\circ}$ (Milligan, 1969) also supports river discharge as the source of the nondetrital iron.

On the basis of the trend surface analyses alone, it is not possible to determine the point(s) of influx of nondetrital manganese into the Kara Sea. Each deeper area reflects a different source, suggesting that factors other than distance from source influence the distribution of nondetrital manganese. These factors include the nature of water masses present in 
given areas as demonstrated by Klenova and Pakhomova (1940) and Kulikov (1961) and probably other redox potential determining factors, such as the content and type of organic matter.

The observation of an increase in the nondetrital $\mathrm{Mn} / \mathrm{Fe}$ ratio in surface sediments away from the mouths of the Siberian rivers is consistent with deposition of most of the nondetrital iron nearer to the points of influx of iron into the Kara Sea. The positive residuals for nondetrital $\mathrm{Mn} / \mathrm{Fe}$ ratio in the central areas of the Sryataya Anna and Voronin Troughs also support deposition of most of the nondetrital iron in shoaler water. These findings are in accord with the suggestions of Murray and Irving (1895) and more recently Skornyakova (1964) and Strakhov and Nesterova (1969) who attributed a real separation of iron and manganese in marine sediments to the greater chemical mobility of manganese compounds in near-shore sediments because of reduction by organic matter. Alternately Price (1967) and Krauskopf (1957) attributed increased $\mathrm{Mn} / \mathrm{Fe}$ ratios on going from littoral to pelagic sediments to the ease of precipitation of iron relative to manganese when river water, charged with soluble divalent ions of these metals, enters the sea. Both processes lead to a seaward (pelagic) enrichment in manganese and thus increased $\mathrm{Mn} / \mathrm{Fe}$ ratios in pelagic sediments.

Although the Siberian rivers are the most logical source of nondetrital iron and manganese in Kara Sea sediments, submarine volcanism, which has been postulated (literature reviewed by Bostrom, 1967) as a major source for nondetrital iron and manganese accumulations in sediments, may theoretically have contributed significant amounts of these elements to Kara Sea sediments. However, this possibility is unlikely because there is no evidence (Saks, 1948; Saks and Strelkov, 1961) of recent submarine volcanic activity in the Kara Sea or the adjacent Barents and Laptev Seas and Arctic Ocean (Strakhov, 1966). Furthermore it seems unlikely that the volcanic activity associated with North Atlantic ridge systems has contributed large amounts of iron and manganese to Kara Sea sediments and not to the sediments of adjacent seas (e.g., Norwegian Sea) which are closer to this obvious volcanic source.
The observation of an expandable clay mineral, which is probably montmorillonite, in Kara Sea sediments (table 2) is not prima facie evidence of a volcanic regime. Applying the criteria of Griffin and Goldberg (1963) for distinguishing volcanic from nonvolcanic montmorillonites in the marine environment to the Kara Sea, it can be established that montmorillonite (1) is not the most abundant mineral in the less than 2 micron fraction, (2) is not associated with the zeolite phillipsite and (3) is not associated with abundant volcanic shards or any of the other products of submarine volcanic effusions such as are reported from the Pacific Ocean by Bonatti and Nayudu (1965). Therefore, montmorillonite in Kara Sea sediments is almost certainly continentally derived.

Variability in the rates of influx of iron and manganese into the Kara Sea, regardless of the source(s) or point (s) of influx, cannot satisfactorily account for the observed distribution of these elements with depth in coles (fig. 8). If this distribution were explained in terms of variability in the rate of influx of either of these elements, it would imply that they are geochemically much more dissimilar than is known to be the case (Rankama and Sahama, 1950). Although there is considerable evidence of preferential, or early, precipitation of iron in soil-forming processes, preferential dissolution and transport of iron unaccompanied by manganese rests on extremely flimsy evidence (Krauskopf, 1957). Thus we would expect the $\mathrm{Mn} / \mathrm{Fe}$ ratio in fluvial waters to remain relatively constant even if the absolute amounts of each element changed.

Eustatic control of the deposition of ferromanganese compounds has been suggested (Goodell, personal communication) to account for cyclic brown banding in delta and nearshore sediments. Under this model rates of detrital sedimentation at low stands of sea level are fast (relatively) in near-shore areas (Huang and Goodell, in press) and chemical elements associated with the finest suspended matter are highly diluted and concentrate only in pelagic areas. At high stands of the sea, rates of sedimentation are comparatively slower in former, i.e., relict, near-shore areas permitting such elements as iron and manganese to concentrate in these areas. During sub- 
sequent lower stands the brown layers formed during high stands are buried under iron-and manganese-deficient sediments and presumably preserved as brown interlayers. Furthermore, because iron is chemically more stable than manganese in near-shore areas, or accumulates more rapidly than manganese in these areas, it is possible that sediments deposited at low stands of sea level are more iron-rich than those deposited in the same area at higher stands of sea level.

Eustatic control of the deposition of nondetrital elements in the Kara Sea is difficult to evaluate at present because of the conflicting evidence of sea level fluctuations in the Kara Sea region during the Quaternary (Lazukov, 1964) and because of the few reliable estimates of rates of sedimentation in the Kara Sea which have been published. That sea level is a significant factor is doubtful because the variability in the $\mathrm{Mn} / \mathrm{Fe}$ ratio in surface sediments (table 14) is relatively low compared with the variability of this ratio with depth in typical cores (tables 12 and 13). If it has been the history of regional variability of this ratio which produced its stratigraphic variability, then the orders of magnitude of both variabilities (regional and stratigraphic) should be similar. Furthermore, development of brown surface layers and interlayers does not seem to have been limited to certain water depth ranges and in fact extends to the greatest depths of the Arctic Ocean (Strakhov, 1966; Belov and Lapina, 1959).

Considerable evidence has been gathered (Murray and Irvine, 1895; Brujevicz, 1938a,b; Mortimer, 1942; Bezrukov, 1960; Manheim, 1965; Lynn and Bonatti, 1965; Strakhov, 1966; Anikouchine, 1967; Price, 1967; Presley, Brooks, and Kaplan, 1967; Li, Bischoff, and Mathieu, 1969) which suggests, and frequently supports, postdepositional redistribution of manganese where oxidizing upper layers are underlain by reducing layers such as in the Kara Sea (fig. 2). This model proposes that manganese, incorporated into accumulating sediments as the oxide, is remobilized after burial by local reducing conditions and diffuses upward in response to the concentration gradient produced by reprecipitation of manganese in upper oxidized strata. The factors which appear most important for the produc- tion of reducing environments in scdiments are the amount and type of decomposable organic matter deposited contemporaneously with the sediment and the rate of accumulation of the sediment (Lynn and Bonatti, 1965). Dissolved oxygen in bottom water, and that which diffuses into the sediment, is probably responsible for the reprecipitation of manganese in upper strata although there is some evidence (Gabe, Troshanov, and Sherman, 1965; Ehrlich, 1966) that bacteria precipitate reduced manganese ions from interstitial water.

The upward enrichment of manganese in typical Kara Sea cores is consistent with the migration model outlined above. The comparatively fast rates of sedimentation ( 4 to $6 \mathrm{~cm}$. per 1,000 years, Kulikov, 1961) apparently favor burial of enough organic matter to produce reducing conditions below the upper oxidizing layers. Reducing conditions in buried layers of Kara Sea sediments are supported by (1) negative redox potentials (Eh) below the upper few centimeters (Trofimov, 1939), (2) $\mathrm{Fe}^{3+} / \mathrm{Fe}^{2+}$ ratios ranging from 0.1 to 2 in gray-green layers as compared with 2 to 20 (and as much as 56) in brown layers (Yermolayev, $1948 a, b)$, and (3) the presence of hydrotroilite in gray-green layers (Klenova, 1948, cited in Strakhov, 1966).

The upward enrichment of iron and its separation from manganese (fig. 8) has apparently not been observed in marine sediments before but is also consistent with the migration model when consideration is given to the greater stability of iron oxides under redox conditions favoring solubilization of manganese oxide and the greater ease of oxidation of reduced iron compared with reduced manganese (Krauskopf, 1957; Hem, 1963). Assuming that manganese and iron have been released into the interstitial water of gray-green layers and that a gradient in oxidation potential exists between the interface, iron should precipitate first from an upward diffusing solution containing both iron and manganese ions even if only inorganic processes are operating.

The models which require reduced rates of sedimentation for formation of blown layers (Arrhenius, 1963; Goodell, personal communication) are not inconsistent with postdepositional redistribution of iron and manganese. In fact, such a rate reduction in the accumulation 
of detrital material may favor development of the elemental distributions such as observed in the present study. Under the influence of a constant, comparatively rapid (4 to $6 \mathrm{~cm} \cdot / 10^{3}$ years), rate of sedimentation, the interface between oxidizing and reducing conditions would be continuously destroyed and new interfaces constructed at progressively higher stratigraphic levels. Presuming that dissolution and diffusion processes in clayey marine sediments are extremely slow, no significant enrichment of iron or manganese in the upper oxidizing layers could take place under conditions of constant rapid sedimentation. On the other hand a period of reduced sedimentation would permit diffusion processes to concentrate the more mobile elements in the upper layers before burial and reduction can remobilize them. In addition, the reduced deposition of detrital matter would permit a relative increase in the primary accumulation in surface layers of nondetrital substances such as ferromanganese colloids and their associated "scavenged" (adsorbed) trace metals. Thus the models proposing primary processes for the development of brown layers and those proposing postdepositional processes need not be mutually exclusive.

It is doubtful that only inorganic processes are important in the postdepositional redistribution of iron and manganese. The activities of bacteria and other microorganisms are thought to play a main role in the decomposition of organic matter and thus production of reducing conditions in sediments ( $\mathrm{Z} \circ \mathrm{Bell}, 1946$ ). The experiments of Yermolayev $(1948 a, b)$ involving the inversion of a typical Kara Sea core clearly demonstrate the role of bacteria in the mobilization of iron and manganese in sediments isolated from gaseous exchange with overlying water. The work of Perfilev et al. (1965) and Ehrlich (1966) also supports the importance of bacteria in the production of reducing condi- tions in sediments, thus solubilizing the iron and manganese, and provides some evidence as to the role of bacteria in the oxidation or precipitation of iron and manganese when the sediments are oxidized. The work of Gabe, Troshanov, and Sherman (1965) is particularly pertinent to the present study because they observed color sequences and iron-manganese distributions in a core from Lake Valk-Yarvi (table 4) identical to those observed in the upper layers of cores $\mathrm{E}-26$ and $\mathrm{N}-1 \mathrm{\Delta} 8$ from the Kara Sea. In addition, they found abundant development of microbes, Metallogenium and Siderococcus, known to derive energy from the oxidation of reduced iron and manganese, in the respective sediment layers enriched in these elements. Whether similar microbes are responsible for the oxidation of jron and manganese in Kara Sea sediments remains to be established.

The existence of secondary (buried) layers, weakly enriched in iron and manganese, implies that not all the nondetrital iron and manganese have been released into interstitial water below the oxidizing zone and migrated upward. This may be due to a nonuniform distribution of organic matter as has been suggested by Oppenheimer (1960) to account for color banding in Texas marine bay sediments. Another possibility is that the iron and manganese in the secondary brown layers have been irreversibly oxidized, as Yermolayev $(1948 a, b)$ has proposed, but are still readily reduced by the hydroxylamine hydrochloride-acetic acid treatment. The occurrence of the iron phosphate, vivianite, as coprolitic concretions in the secondary brown layers of cores E-31 and N-77 is almost certainly authigenic and may imply higher biological productivity, possibly in response to an influx of warmer waters as proposed by Yermolayev $(1948 a, b)$, at the time these layers were deposited.

\section{Conclusions}

This textural, mineralogical and geochemical study of Kara Sea sediments allows the following conclusions and generalities to be drawn regarding the significance of color variations in the upper layers:

1. The color sequences observed in typical
Kara Sea cores are not related to stratigraphic variability in texture or detrital mineralogy.

2. Nondetrital iron and manganese compounds are the constituents of Kara Sea sediments which impart the brown color to the upper layers. 
3. The source $(s)$ or point $(s)$ of influx into the Kara Sea of iron and manganese is (are) probably the Siberian rivers which enter the sea from the south.

4. Factors other than distance from source $(s)$ or point (s) of influx apparently control the distribution of nondetrital manganese in the surface sediments of the Kara Sea.

5. Nondetrital manganese may be transported farther from its point(s) of influx into the Kara Sea than nondetrital iron, or be chemically more stable in the deeper areas of the Kara Sea.

6. The distribution of nondetrital iron and manganese, and thus color, with depth in Kara Sea cores appears to be controlled by postdepositional processes, including dissolution, migration, and subsequent differential oxidation of reduced iron and manganese ions, rather than by primary depositional processes.

\section{Acknowledgement}

This study was partially supported from June 1969 to June 1970 by a U.S. Coast Guard cooperative study program.

\section{References}

Andrew J. A., in preparation, A sedimentological study of the Kara Sea, north of $76^{\circ}$ North: Ph. D. dissertation, University of Wisconsin.

Andrew, J. A., and Kravitz, J. H., 1968, Surface sediments of the Kara Sea (ahstract): Bull. Am. Ass. Petrol. Geol., v .52, pp. 517-518.

Anikouchine, W. A., 1967, Dissolved chemical substances in compacting marine sediments: J. Geophys. Res., v. 72, pp. 505-509.

Arrhenius, G., 1963, Pelagic sediments, pp. 655-727 in Hill, M. N., Editor, The sea, v. 3: Interscience Publ., New York.

Belov, N. A., and Lapina, N. N., 1959, Relief, bottom sediments and geological history of the central Arctic as related to hydrological conditions (abstract): Prepr., First Int. Oceanogr. Congr., pp. 11-12.

Bezrukov, P. L., 1960, Sedimentation in the northwestern Pacific Ocean: Int. Geol. Congr., 21st, Copenhagen, 1960, Rep. Sov. Geol., pp. 45-58.

Biscaye, P. E., 1965. Mineralogy and sedimentation of Recent deep-sea clay in the Atlantic Ocean and adjacent seas and oceans: Bull. Geol. Soc. Am., v. 76, pp. 803-832.

Bonatti, E., and Nayudu, Y. R., 1965, The origin of manganese nodules on the ocean floor: Science, v. 263, pp. 17-39.

Bostrom, K., 1967, The problem of excess manganese in pelagic sediments, pp. 421-452 in Abelson, P. H., Editor, Researches in geochemistry, v. 2: John Wiley and Sons, Inc., New York.

Brujevicz, S. W., 1938a, Oxidation-reduction potential and the $\mathrm{pH}$ of sediments of the Barents and Kara Seas: Compt. rend. Acad. Sci., URSS, v. 19, pp. 637-640.

Brujevicz, S. W., 1938b, Oxidation-reduction potentials and $\mathrm{pH}$ of sea bottom deposits: Verhandl. d. internat.
Vereinigung f. theor. . angew. Limnologie, v. 8, pp. $35-49$.

Chester, R., and Hughes, M. J., 1966, The distribution of manganese, iron and nickel in a North Pacific deepsea core: Deep-sea Res., v. 13, pp. 627-634.

Chester, R., and Hughes, M. J., 1967, \& chemical technique for the separation of ferro-manganese minerals, carbonate minerals and adsorbed trace elements form pelagic sediment: Chem. Geol., v. 2, pp. 249-262.

Chester, R., and Hughes, M. J., 1969, The trace element geochemistry of a North Pacific pelagic clay core: Deep-Sea Res., v. 16, pp. 639-654.

Dibner, V. D., 1957, The geological structure of the central part of the Kara Sea, pp. 222-238 in Markov, F. G., and Nalivkin, D. V., Editors, Geology of the Soviet Arctic [in Russian], v. 81 (transl. by K. Price and W. A. Kneller, Eastern Michigan Univ., Ypsilanti, Michigan).

Ehrlich, H. L., 1966, Reactions with manganese by bacteria from marine ferromanganese nodules: Developments in Industrial Microbiology, v. 7, pp. 279-286.

Fairbridge, R. W., 1966 Kara Sea, pp. 430-432 in Fairbridge, R. W., Editor, Encyclopedia of Oceanography, Rheinhold Publ. Co., New York.

Folk, R. L., 1965, Petrology of sedimentary rocks: Hemphill's, Austin, Tex., 159 pp.

Gabe, D. R., Troshanov, F. P., and Sherman, E. E., 1965, The formation of manganese-iron layers in mud as a biogenic process, pp. 88-105 in Perfil'ev, B. V. et al., Applied capillary microscopy (transl. from Russian by F. L. Sinclair): Consultants Bureau, New York.

Garcia, A. W., 1969, Oceanographic observations in the Kara and Eastern Barents Seas: U.S. Coast Guard Oceanogr. Rep., No. 373-26, 99pp. 
Gibbs, R. J., 1965, Error due to segregation in quantitative clay mineral $\mathrm{X}$-ray diffraction mounting techniques: An. Miner., v. 50, pp. 741- 751.

Goodell, H. G., 1967, The sediments and sedimentary geochemistry of the southeastern Atlantic Shelf: J. Geol., v. 75, pp. 665-692.

Gorshkova, T. I., 1957, Sediments of the Kara Sea [in Russian]: Trudy Vsessouzn. Gidrobiol. Obshch., v. 8, pp. 68-99 (Transl. No. 333, USN Oceanogr. Off.).

Gorshkova, T. I., 1966, Manganese in the sediments of the northern seas, pp. 140-141 in Vinogradov, A. P., Editor, Second Int. Ocetanogr. Congr. Abstract of Papers: Publishing House Nauka, Moscow.

Griffin, J. J., and Goldberg, E. D., 1963, Clay-mineral distribution in the Pacific Ocean, pp. 728-741 in Hill, M. N., Editor, The sea, v. 3: Interscience Publ., New York.

Hen, J. D., 1963 Chemical equilibria affecting the behavior of manganese in natural water: Bull. Int. Ass. Scient. Hydrol., v. 8, pp. 30-37.

Huang, T. C., and Goodell, H. G., in press, The sediments and sedimentary processes of the Eastern Mississippi Cone, Gulf of Mexico: Am. Ass. Petrol. Geol.

Johnson, G. L., and Milligan, D. B., 1967, Some geomorphological observations in the Kare Sea: Deep-Sea Res., v. 14, pp. 19-28.

Keller, W. D., 1953 Illite and montmorillonite in green sedimentary rocks: J. Sed. Petrol., v. 23, pp. 3-9.

Klenova, M. V., 1936, Sediments of the Kara Sea: Compt. rend. Acad. Sci., URSS, v. 4, pp. 187-190.

Klenova, M. V., 1938 Colouring of polar sea sediments: Compt. rend. Acad. Sci., URSS, v. 19, pp. 629-632.

Klenova, M. V., and Pakhomova, A. S., 1940, Manganese in the sediments of polar seas: Compt. rend. Acad. Sci., URSS, v. 28, pp. 87-89.

Krauskopf, K. B., 1957, Separation of manganese from iron in sedimentary processes: Geochim. cosnochim. Acta, v, 12, pp. 61-84.

Krumbein, W. C., 1959, Trend surface analysis of contour-type maps with irregular control-point spacing. J. Geophys. Res., v. 64, pp. 823-834.

Krumbein, W. C., and Sloss, L. L., 1963, Stratigraphy and sedimentation: W. H. Freeman and co., San Francisco, $660 \mathrm{pp}$.

Kulikov, N. M., 1961, Sedimentation in the Kara Sea [in Russian], pp. 437-447 in Sovremennye osadki morei iokeanov: Akad. Nauk SSSR (Transl. No. 317, USN Oceanogr. Off.).

Lazukov, G. I., 1964, Variations in the level of the Polar Basin in the Quarternary Period [in Russian]: Okeanologiia, v. 4, pp. 174-181.

Li, Y. H., Bischoff, J., and Mathieu, G., 1969, The migration of manganese in the Arctic Basin sediment: Earth Planet. Sci. Lett. v. 7, pp. 265-270.

Lynn, D. C., and Bonatti, E., 1965, Mobility of manganese in diagenesis of deep-sea sediments: Mar. Geol., v. 3 , pp. $457-474$.

Manheim, F. T., 1965, Manganese-iron accumulations in the shallow marine environment: Proc. Symp. mar. Geochem., Univ. Rhode Island, Occ. Pub. No. 3, pp. $317-276$.
Markov, F. G., and Tkachenko, B. V., 1961, The Paleozoic of the Soviet Arctic, pp. 31-47 in Raasch, G. O., Editor, Geology of the Arctic, v. 1: University of Toronto Press.

Miller, R. L., 1956, Trend surfaces, their application to analysis and description of environments of sedimentation: J. Geol., v. 64, pp. 425-446.

Milligan, D. B., 1969, Oceanographic survey results, Kara Sea, summer and fall, 1965: Tech. TR-217, USN Oceanogr. Off., pp. 1-64.

Mortimer, C., 1942, The exchange of dissolved substances between mud and water i nlakes: J. Ecol., v. 30, pp. 147-201.

Murray, J., and Irvine, R., 1895, On the manganese oxide and manganese nodules in marine deposits: Roy. Soc. Edinburgh Trans., v. 37, pp. 721-742.

Nalivkin, D. V., 1960, The geology of the USSR, a short outline: Pergamon Press, New York, 170 pp.

Nesterova, I. L., 1900 , Chemical composition of the suspended and dissolved loads of the $\mathrm{Ob}$ River: Geochemistry, No. 4, pp. 424-431.

Nordenskjold, O., and Mecking, L., 1928, The geography of the Polar regions: Am. Geogr. Soc., Spec. Pub. No. 8, New York.

Oppenheimer, C. H., 1960, Bacterial activity in sediments of shallow marine bays: Geochem. cosmochim. Acta, v. 19, pp. 244-260.

Perfil'ev, B. V., Gabe, D. R., Gal'perina, A. M., Rabinovich V. A., Sapotnitskii, A. A., Sherman, E. E., and Troshanov, E. P., 1965, Applied capillary microscopy - The role of microorganisms in the formation of iron-manganese deposits (transl. by F. L. Sinclair): Concultants Bureau, New York, 122 pp.

Presley, B. J., Brooks, R. R., and Kaplan, I. R., 1967, Manganese and related elements in the interstitial water of marine sediments: Science, v. 158, pp. 906-909.

Price, N. B., 1967, Some geochemical observations on the manganese-iron oxide nodules from different depth environments: Mar. Geol., v. 5, pp. 511-538.

Rabkin, M. I., and Ravich, M. G., 1961, The Precambrian of the Soviet Arctic, pp. 18-30 in Raasch, G. O., Editor, Geology of the Arctic, v. 1: University of Toronto Press.

Rankama, K., and Sahama, Th. G., 1950, Geochemistry: The University of Chicago Press, Chicago and London, $912 \mathrm{pp}$.

Rich, C. I., 1968, Hydroxy interlayers in expansible layer silicates: Clays and Clay Minerals, v. 16, pp. 15-30.

Sachs, V. N., 1948, Quaternary Period in the Soviet Arctic [in Russian]: Trudy ark. nauchno-issled Inst., v. 201, pp. $12-17,62-74$ (Transl. No. 338, USN Oceanogr. Off.).

Sachs, V. N., and Strelkov, S. A., 1961, Mesozoic and Cenozoic of the Soviet Arctic, pp. 48-67 in Raasch, G. O., Editor Geology of the Arctic, v. 1: University of Toronto Press.

Shapiro, L., 1967, Rapid analysis of rocks and minerals by a single-solution method: Prof. Pap., U.S. Geol. Surv., 575-B, pp. 187-191. 
Shepard, F. P., 1954, Nomenclature based on sand-siltclay ratios: J. Sed. Patrol., v. 24, pp. 151-158.

Skornykova, 1. S., 1964, Dispersed iron and manganese in Pacific Ocean sediments: Int. Geol. Rev., v. 7, pp. 2161-2174.

Strakhov, N. M., 1966, Types of manganese accumulation in present-day basins, their significance in understanding of manganese mineralizaticn: Int. Geol. Rev., v. 8, pp. 1172-1196.

Strakhov, N. M., and Nesterova, 1. L., 1969, Effects of volcanism on the geochemistry of marine deposits in the Sea of Okhotsk: Geochen. Int., v. 5, pp. 644-666.

Trofimov, A. V., 1939, Oxidizing activity and $\mathrm{pH}$ of brown sediments of the Barents Sea: Compt. rend. Acad. Sci., URSS, v. 23, pp. 925-928.

Weller, J. M., 1960, Stratigraphic principles and practice: Harper and Bros., New York, 725 pp.
Yermolayev, M. M., 1948a, Lithogenesis of plastic clay sediments in seas [in Russian]: Izv. Akad. Nauk SSSR Ser. Geol., No. 1, pp. 121-138 (Transl. No. 355, USN Oceanogr. Off.).

Yernolayev, M. M., 1948b, The prob'em of historical hydrology of seas and oceans [in Russian]: Vop. Geogr. Klimatol. Gidrol., v. ,7pp. 27-36 (Transl. No. 346, USN Oceanogr. Off.).

Zenkevitch, L. A., 1963, Biology of the seas of the USSR: Interscience Publishers, New York, 955 pp.

Zenkovitch, V. P., Leontiev, O. K., and Nevessky, E. N., 1960 , Influence of the eustatic post-glacial transgression upon the development of the coastal zone of the USSR seas: 21st Int. Geol. Congr. Proc., pt. 10, pp. $65-72$.

ZoBell, C. E., 1946, Studies of redox potential of marine sediments: Bull. Am. Ass. Petrol. Geol., v. 30 , pp. $477-513$. 


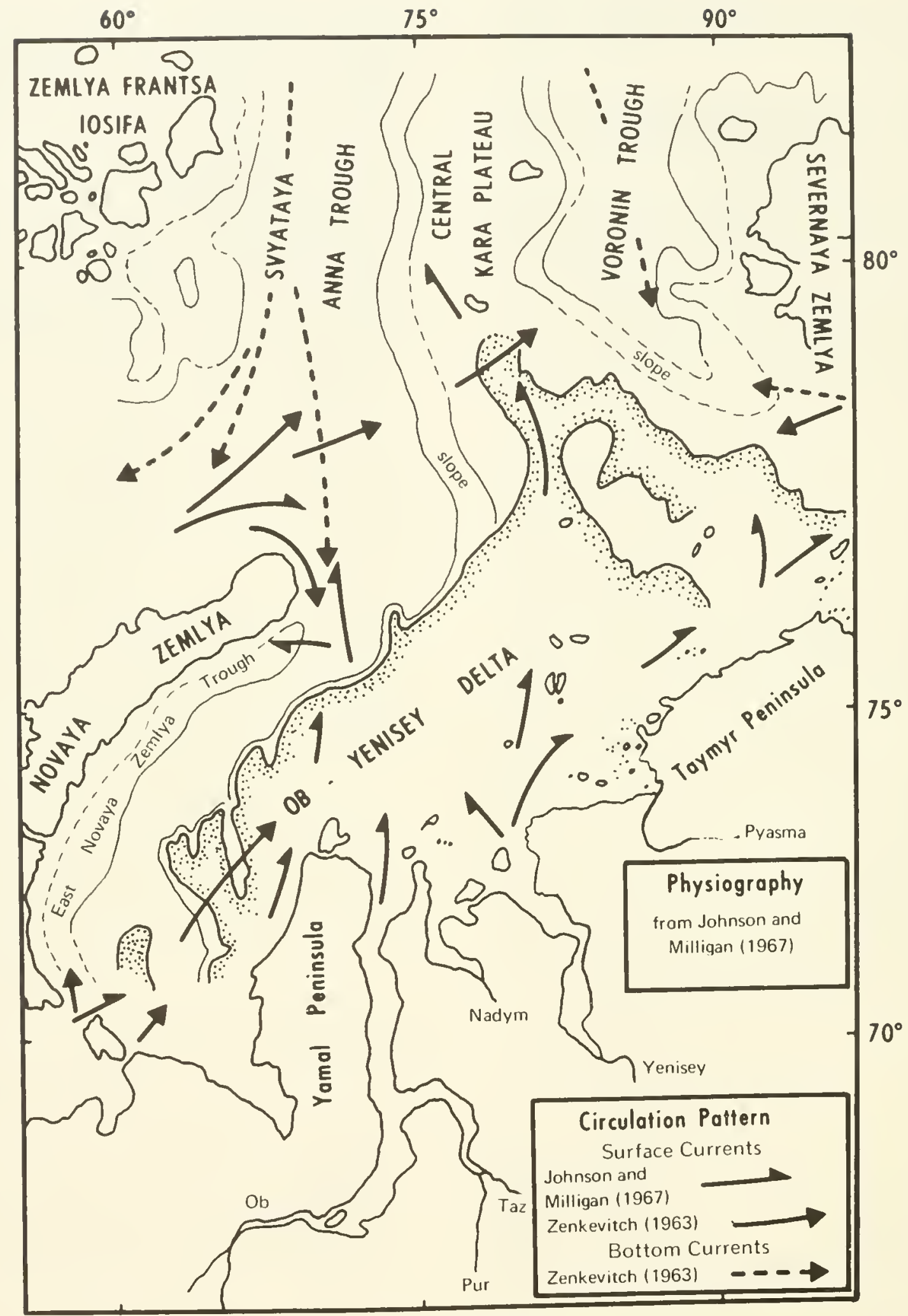

Figure 1. Physiography and circulation pattern of the Kara Sea. 
Redox Potential ( $m V$ )
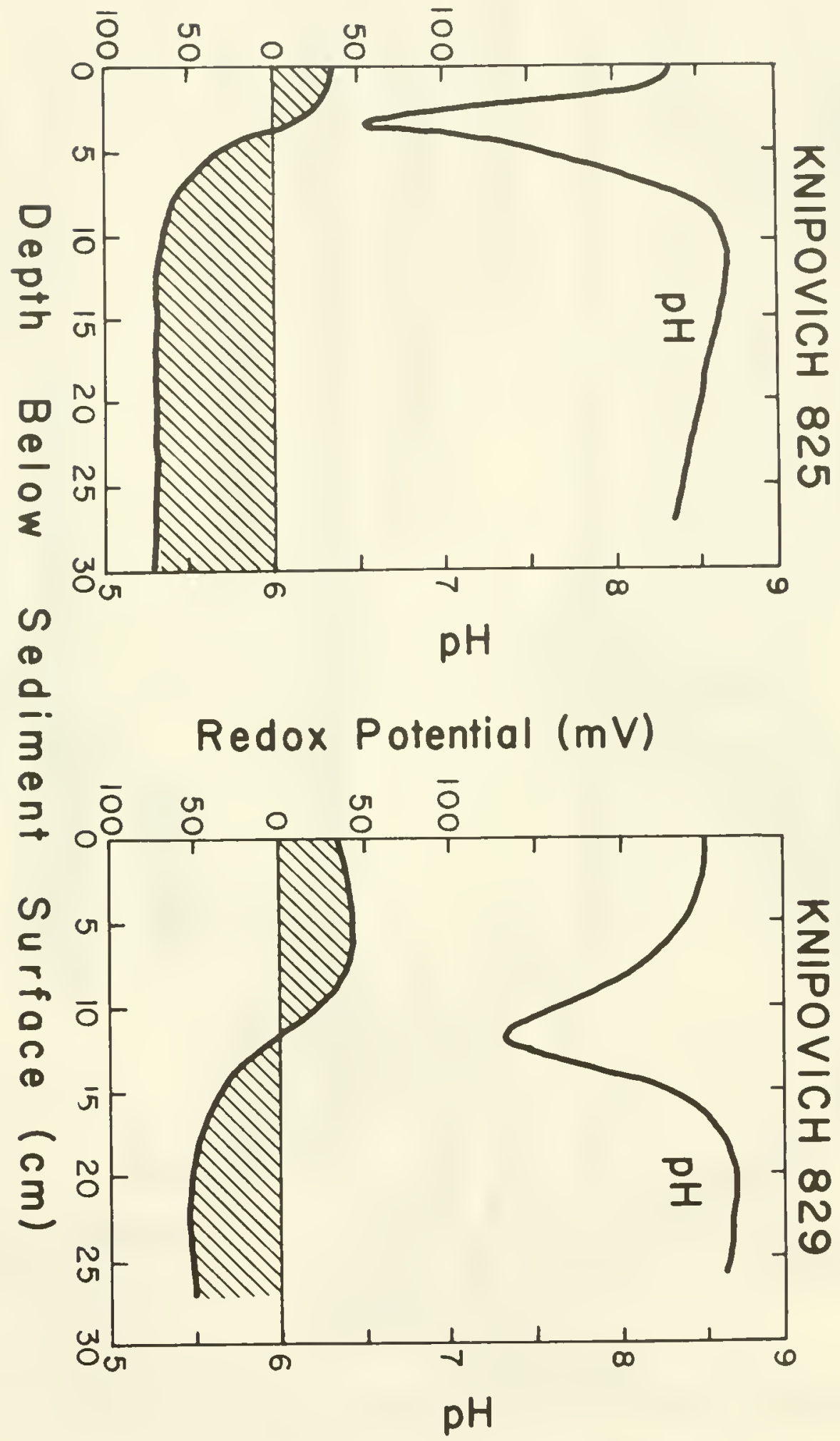

Figure 2. Redox potential and $\mathrm{pH}$ in two KNIPOVICH cores from the Kara Sea. 


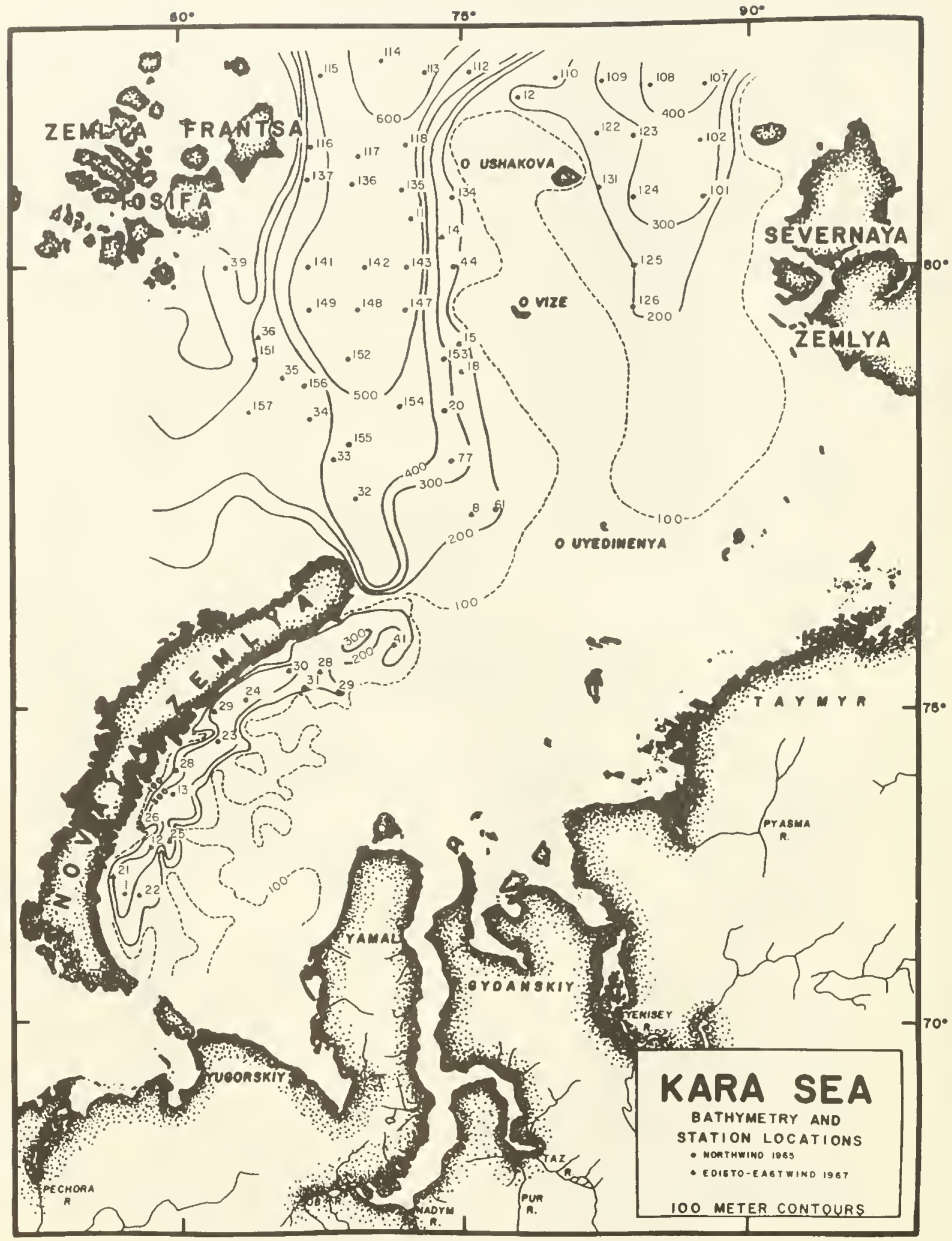

Figure 3. Station locations and bathymetry. 


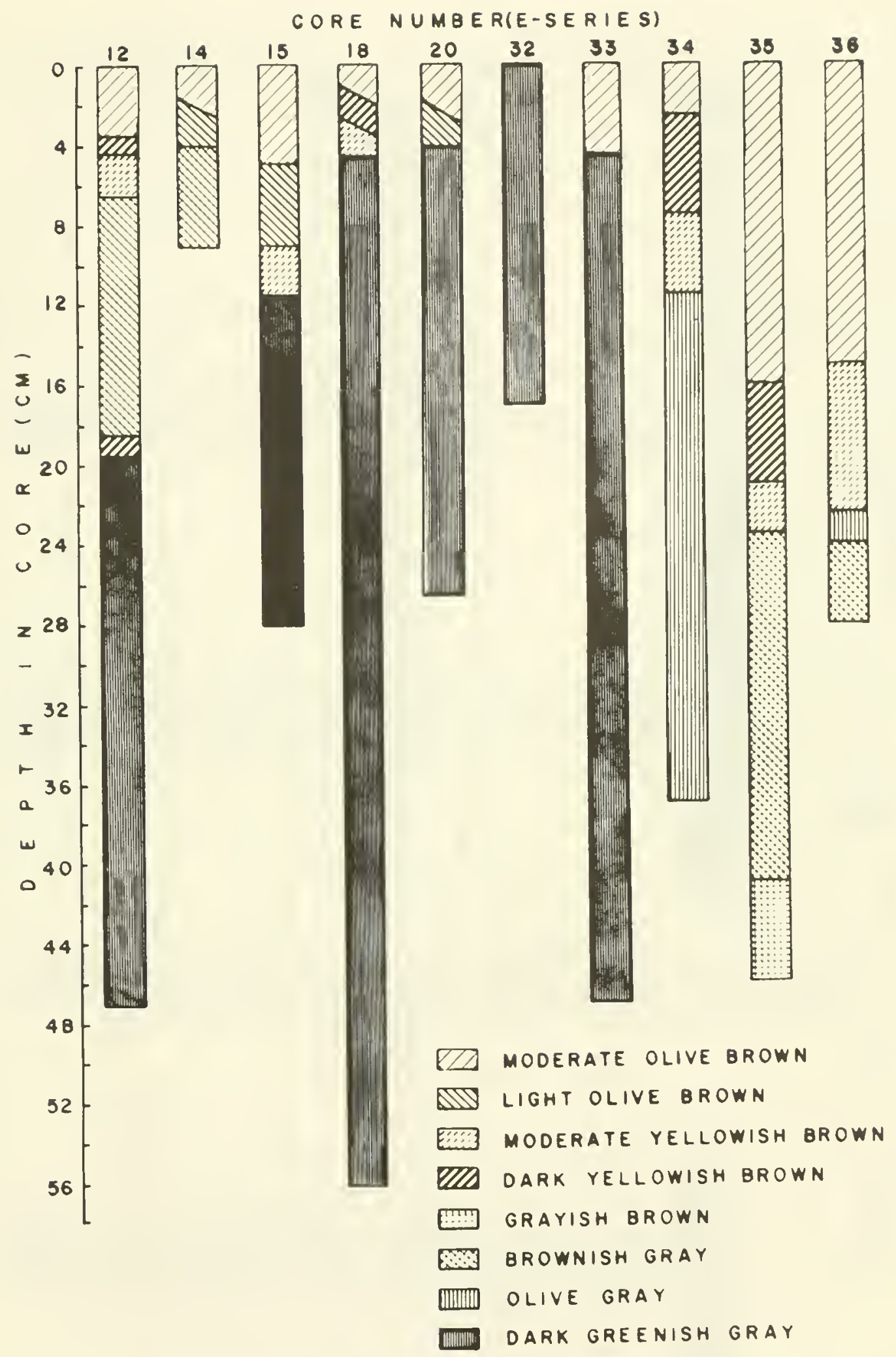

Figure 4. Color variations with depth in 10 cores from the northern Kara Sea. 


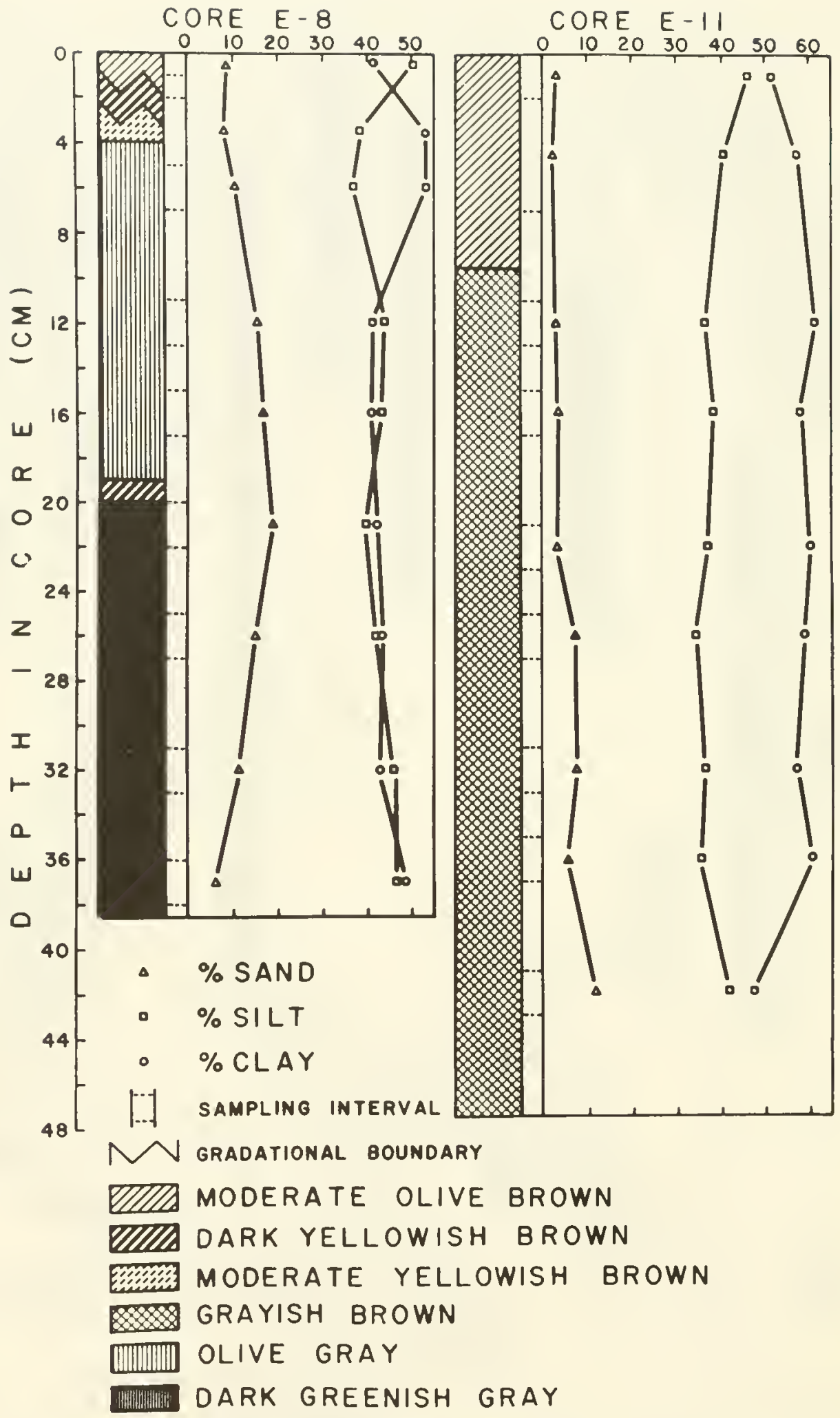

Figure 5. Color variations and distribution of gravel, sand, silt and clay with depth in cores from stations E-8 and E-11 (Sryataya Anna Trough). 

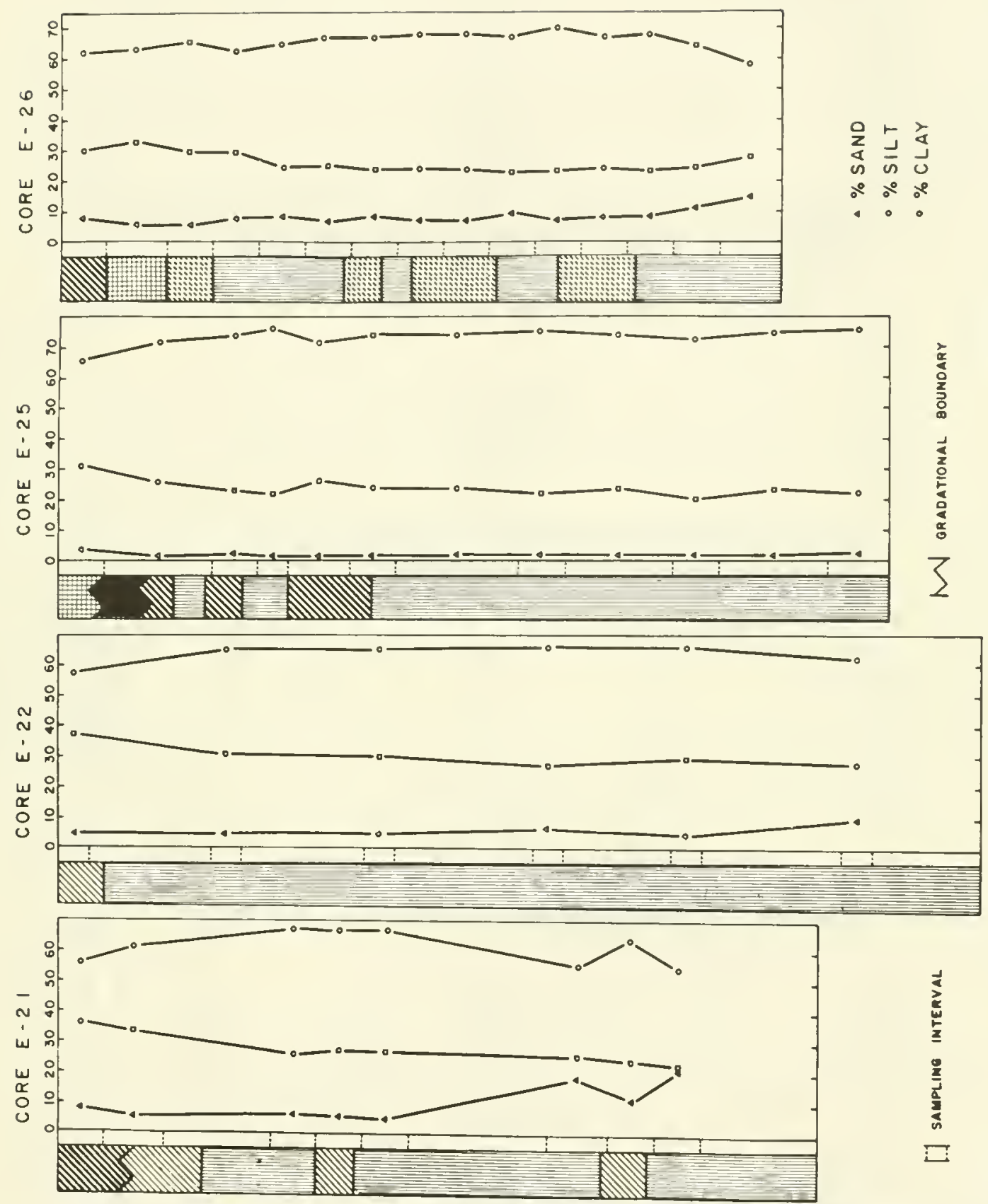

$\begin{array}{lll}0 & 5 \\ 2 & 1 & 4 \\ 4 & \overline{1} & 0 \\ 0 & 0 & 0 \\ 0 & 0\end{array}$

जิ

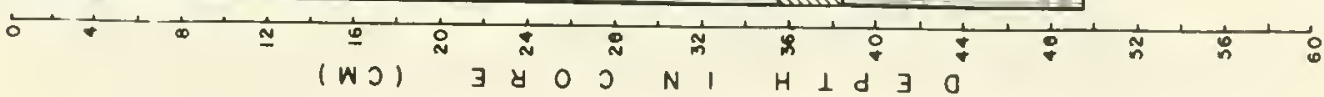



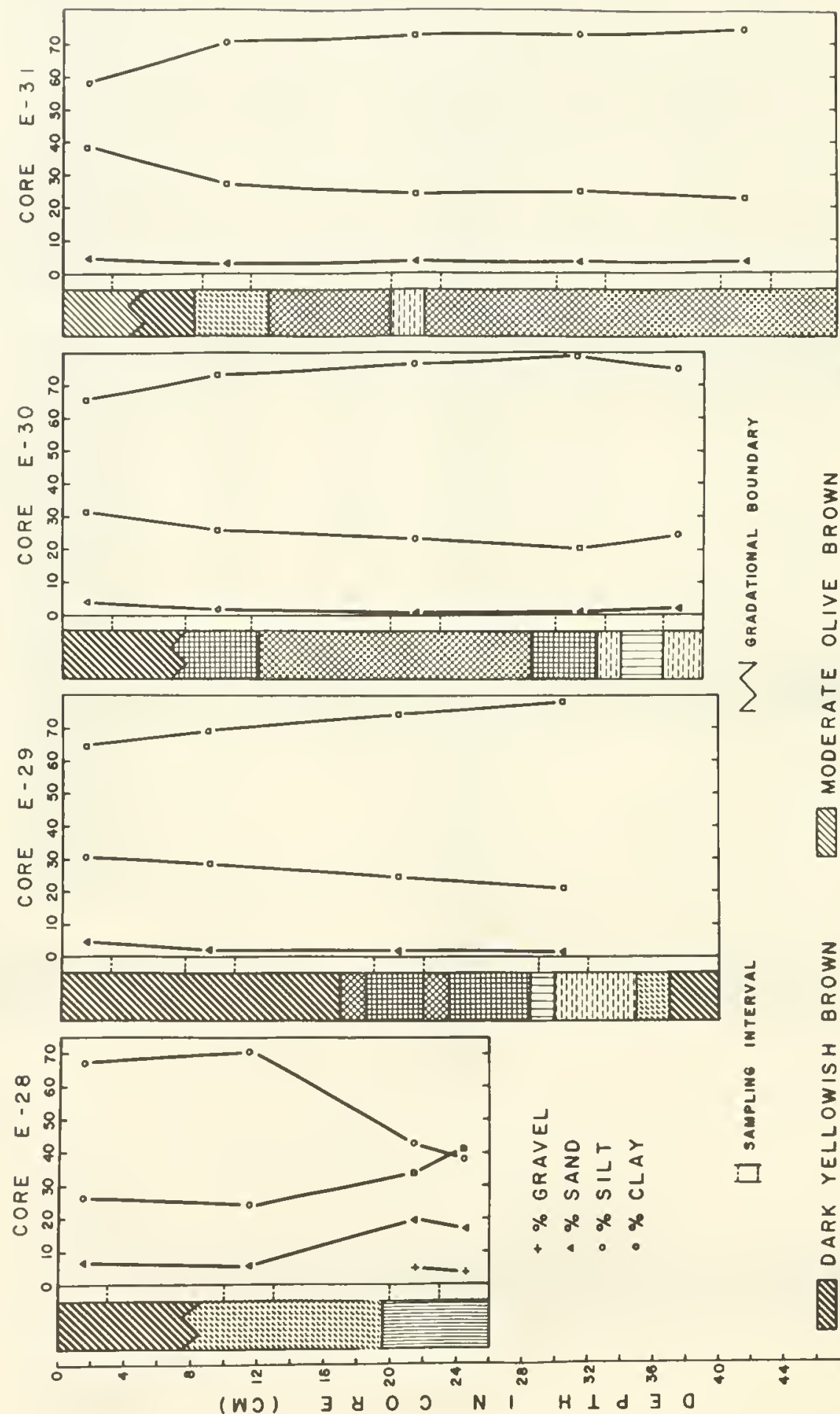

藏

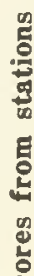

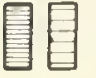

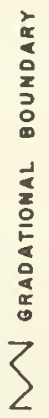

.5

2
3
0
0
0
0

uz>

ग

व

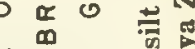

แ I

๔

山 $2 \frac{2}{3}$

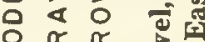

舟

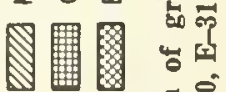

A

2

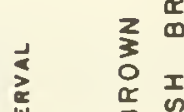

I

工 32

- 동.

ż山

西

更

ш

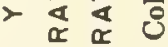

希

\& 응응

N

(WD) 3 \& 00 N I H 


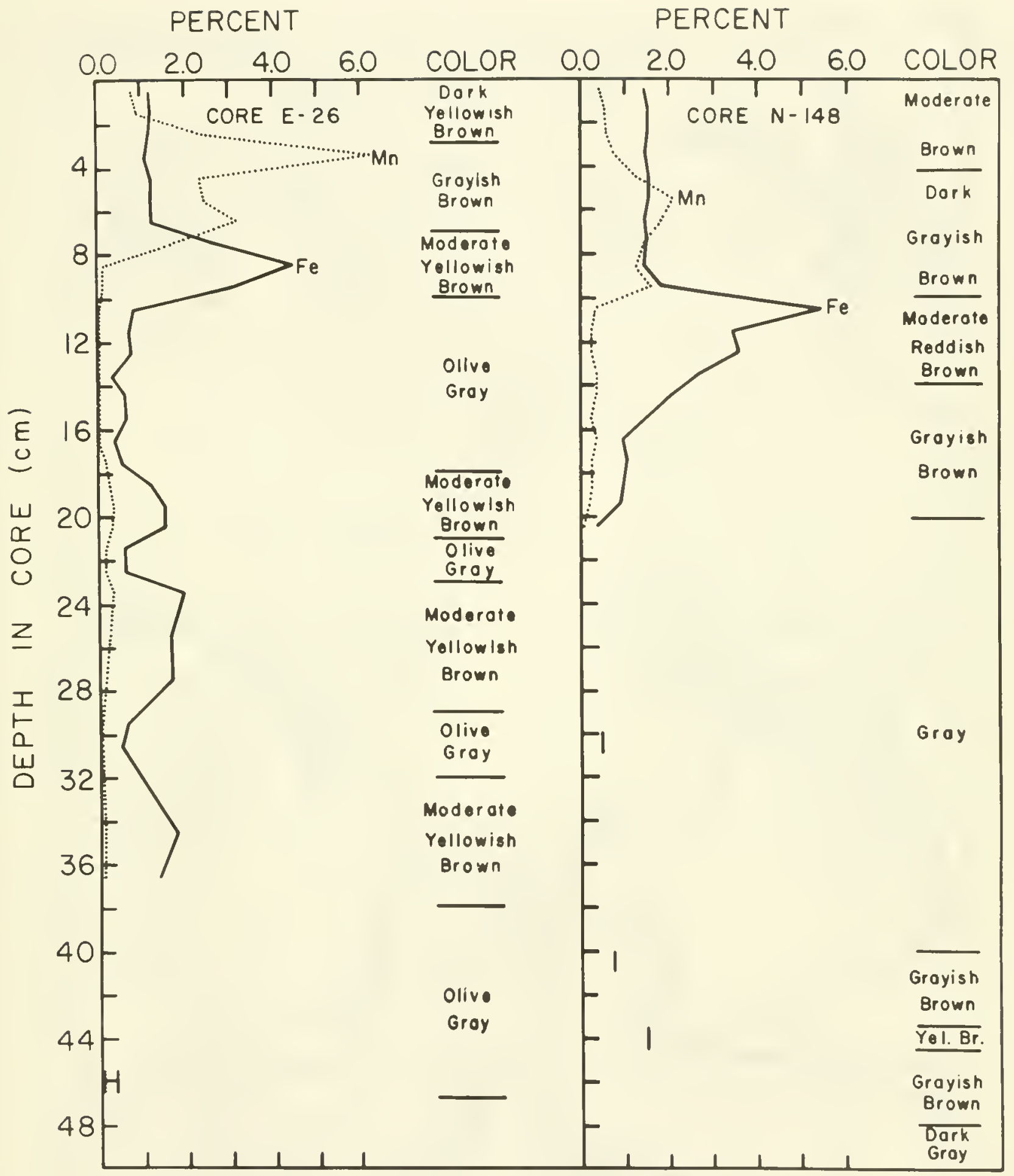

Figure 8. Distribution of nondetrital iron and manganese and color in core $\mathrm{E}-26$ andN-148. 


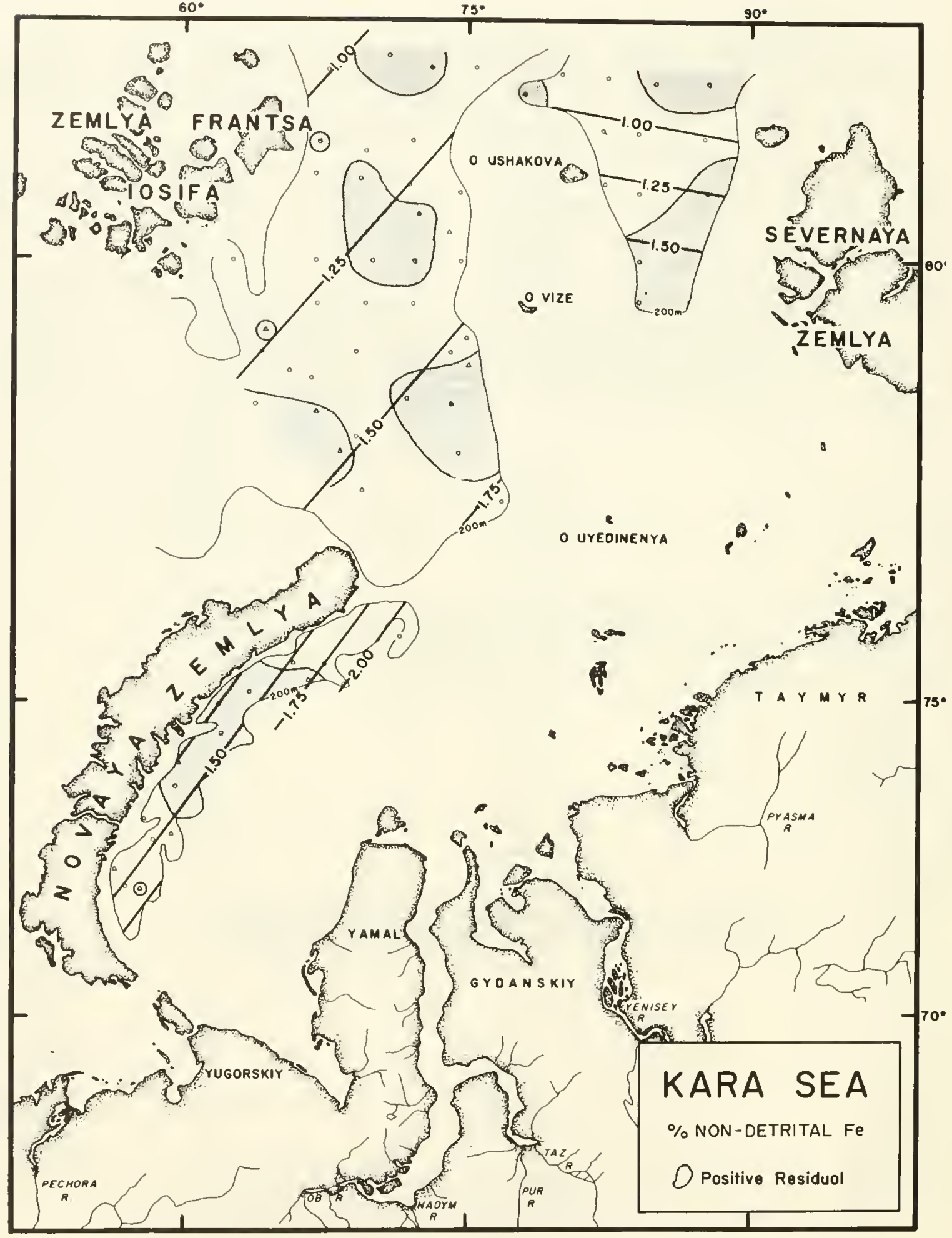

Figure 9. Percent nondetrital iron in surface sediments (linear trend surface). 


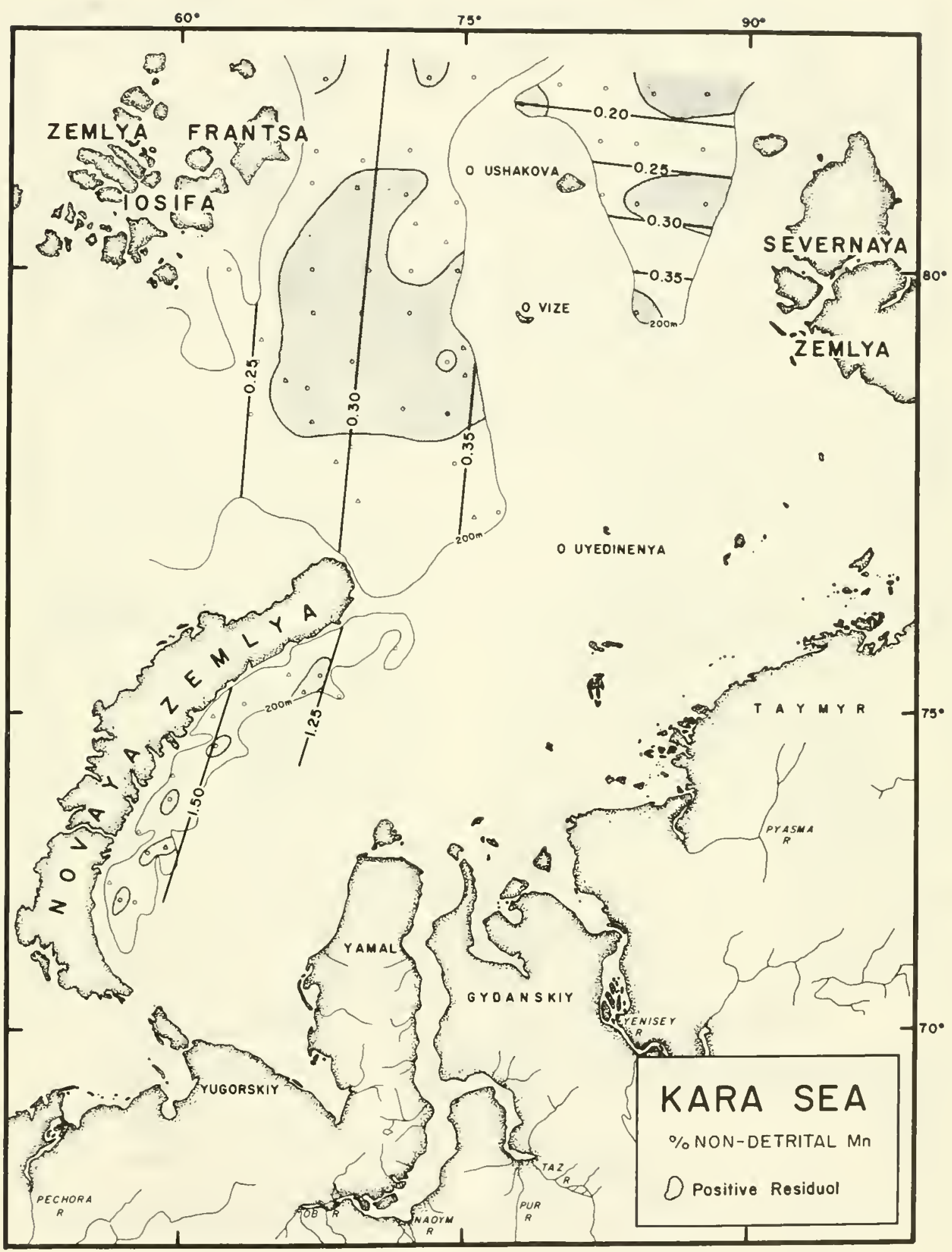

Figure 10. Percent nondetrital manganese in surface sediments (linear trend surface). 


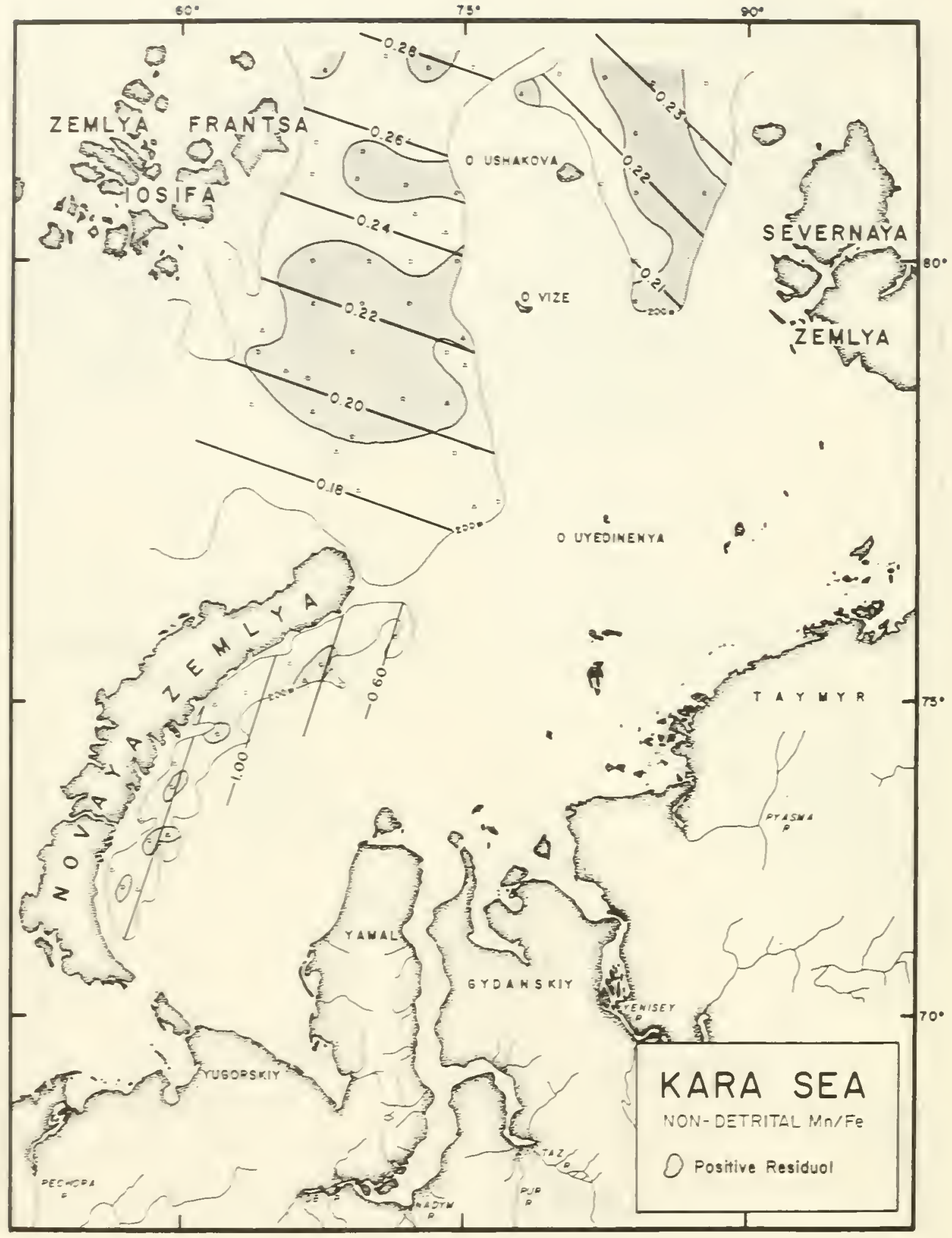

Figure 11. Sondetrital Mn/Fe Ratio in surface sediments (linear trend surface). 


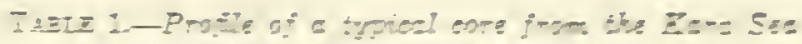

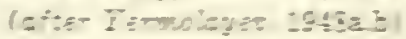

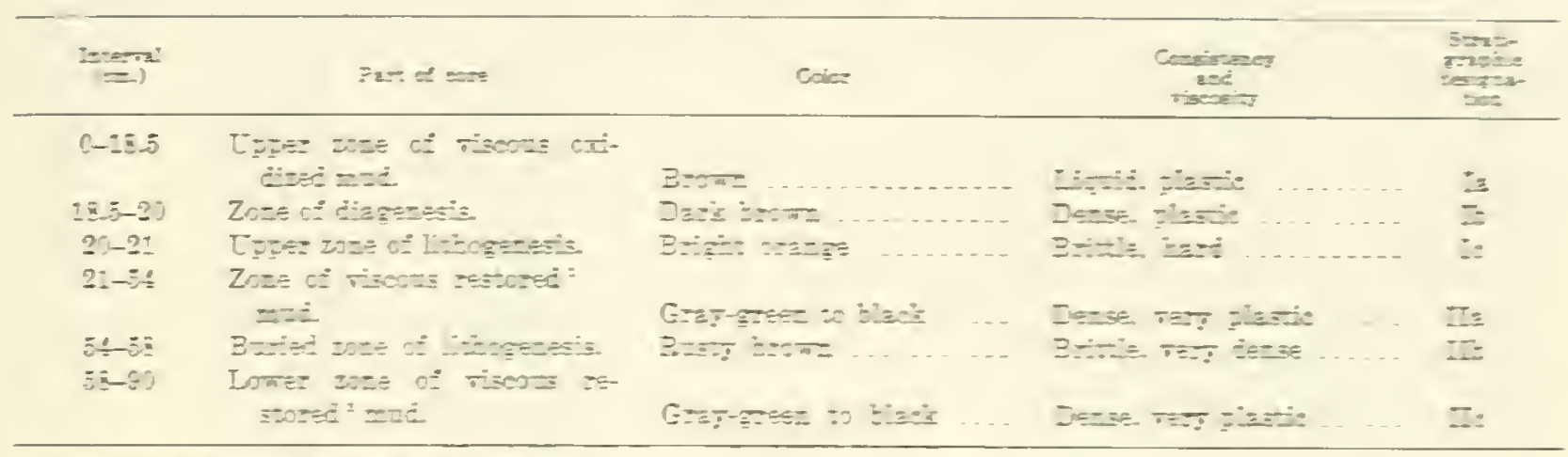

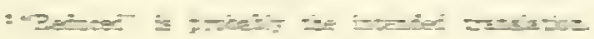

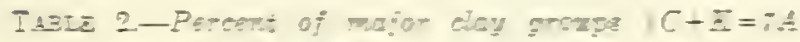

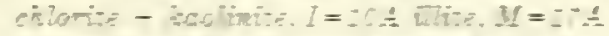

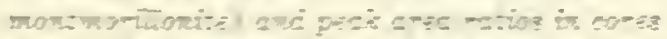

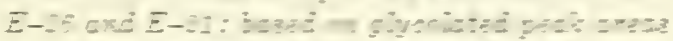

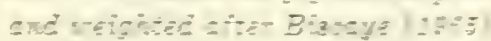

\begin{tabular}{|c|c|c|c|c|c|c|}
\hline I-x=! & $c-\underline{E}$ & 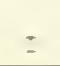 & $x$ & $\frac{c-5}{z}$ & $\frac{y}{2}$ & $\frac{y-x}{x-3}$ \\
\hline \multicolumn{7}{|c|}{$\Gamma_{x \rightarrow E-2}$} \\
\hline $0-3$ & 32 & $\div$ & 20 & . $=5$ & C.I & $\Xi=$ an \\
\hline $3-7$ & 23 & $\div 2$ & 55 & $=\div$ & $\because=2$ & In. \\
\hline i- & 25 & 35 & $\because-3$ & 50 & $=2$ & Dn. \\
\hline $20-3$ & 22 & 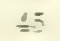 & 33 & $\therefore \leq \bar{E}$ & $c .9$ & $G= \pm !$. \\
\hline $13-=5$ & 27 & $\because 2$ & $3:$ & $0=3$ & $1 .-3$ & $D C$. \\
\hline$\therefore 5-25$ & 27 & 3 & $\because$ & $=58$ & 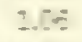 & $D=$ \\
\hline $10-22$ & 20 & $\because$ & 5 & $0=2$ & 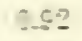 & $E=-=$ \\
\hline $39-12$ & 22 & :- & $2 \overline{1}$ & 2.43 & $c \equiv z$ & $G= \pm$ \\
\hline \multicolumn{7}{|c|}{$C_{6}=\bar{\Sigma}-8$} \\
\hline $0-3$ & 32 & $\because \because$ & $2 \div$ & 6.22 & 0.53 & $3=0 x=$ \\
\hline $3-7$ & $\approx$ & $\varepsilon q$ & 38 & 0.55 & $0 \leq z$ & $D=$. \\
\hline $1 \div=-7$ & $=$ & $3 \%$ & 50 & 6.53 & $2=0$ & $C= \pm 5$ \\
\hline $17-23$ & 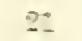 & 32 & $\because 7$ & D.EF & 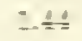 & इःगन- \\
\hline $22-23$ & 13 & $3 \div$ & 53 & $0=$ & 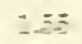 & $G= \pm$. \\
\hline $32-5=$ & 22 & $\because$ & 37 & 0.53 & $0.5=2$ & $D=$ \\
\hline $3=-39$ & $=$ & 3 & $\stackrel{2}{=}$ & 0.2 & 1.7 & $3 x-=$ \\
\hline $30 \div 2$ & 23 & 33 & $\because$ & $0.5 ?$ & $z=$ & $C= \pm !$. \\
\hline
\end{tabular}

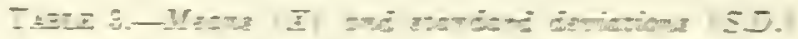

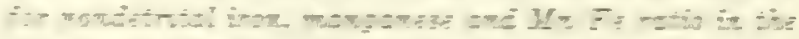
z) -

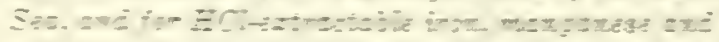

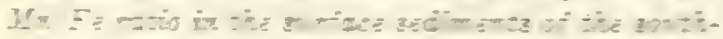

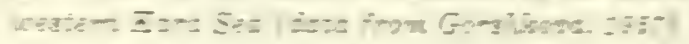

\begin{tabular}{|c|c|c|c|c|c|c|}
\hline & \multicolumn{2}{|c|}{$\Xi \equiv$} & \multicolumn{2}{|c|}{$x=$} & \multicolumn{2}{|c|}{$x-I \equiv$} \\
\hline & $\overline{3}$ & $\equiv$ & $\overline{3}$ & 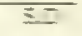 & $\bar{E}$ & $\overline{35}$ \\
\hline 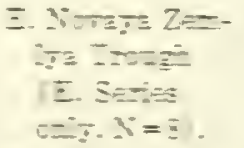 & $\because 5$ & $\therefore=9$ & $\because:$ & $\therefore \approx z$ & $\therefore=?$ & 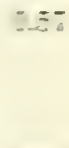 \\
\hline 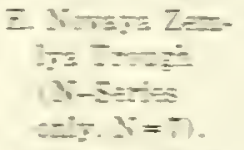 & $E \equiv$ & $=2$ & $\because E$ & $\therefore z$ & $=80$ & $\ldots$ \\
\hline 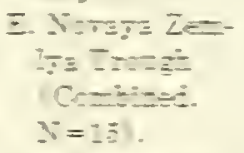 & $=5$ & 0 & $2 \div \div$ & $3=5$ & $2: 3$ & $\because-$ \\
\hline 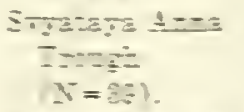 & $=3 \div$ & $=3$ & 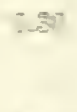 & $\ldots$ & $\infty$ & $9=$ \\
\hline 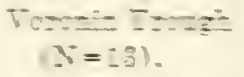 & E.t: & -35 & $-5=$ & $\because$ & $=0$ & $\ldots+$ \\
\hline $\begin{array}{c}\text { Gors:-atz DE⿰ } \\
M=3: .\end{array}$ & $\div 28$ & $\pm=$ & $=\ldots$ & $-\therefore ?$ & lnes & 0.5 \\
\hline
\end{tabular}

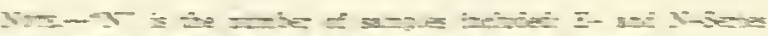

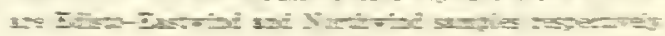


TABLE 4.-Distribution of manganese and iron oxides in secondary microzonal profile of mud from LAKE

VALK-YARVI (after GABE et al., 1965)

\begin{tabular}{|c|c|c|c|}
\hline \multirow{2}{*}{ Horizon } & \multicolumn{2}{|c|}{ Percent } & \multirow{2}{*}{ Remarks } \\
\hline & $\mathrm{Mn}_{2} \mathrm{O}_{3}$ & $\mathrm{Fe}_{2} \mathrm{O}_{3}$ & \\
\hline Oxidizing horizon - & 0.93 & 1.90 & \\
\hline $\begin{array}{l}\text { Black-brown } \\
\text { microzone. }\end{array}$ & 6.03 & 3.60 & $\begin{array}{l}\text { Abundant develop- } \\
\text { ment of Metallo- } \\
\text { genium. }\end{array}$ \\
\hline Orange microzone & 0.46 & 8.90 & $\begin{array}{l}\text { Abundant develop- } \\
\text { ment of Sidero- } \\
\text { coccus. }\end{array}$ \\
\hline Reducing horizon & 0.33 & 2.71 & \\
\hline
\end{tabular}

TABLE 5.-Station positions and water depths for Northwind (1965); sediment samples

\begin{tabular}{|c|c|c|c|}
\hline $\begin{array}{l}\text { Station } \\
\text { No. }\end{array}$ & $\begin{array}{l}\text { Latitude } \\
\text { (N) }\end{array}$ & $\begin{array}{l}\text { Longitude } \\
\text { (E) }\end{array}$ & $\begin{array}{c}\text { Depth } \\
\text { (meters) }\end{array}$ \\
\hline 61 & $77-31.8$ & $76-42.0$ & 280 \\
\hline 77 & $78-03.4$ & $74-38.0$ & 362 \\
\hline 101 & $80-36.0$ & $87-39.0$ & 310 \\
\hline 102 & $81-04.0$ & $87-32.0$ & 340 \\
\hline 107 & $81-30.5$ & $87-39.0$ & 420 \\
\hline 108 & $81-30.5$ & $84-54.0$ & 410 \\
\hline 109 & $81-32.7$ & $82-18.0$ & 315 \\
\hline 110 & $81-34.8$ & $79-52.0$ & 203 \\
\hline 112 & $81-37.0$ & $75-20.0$ & 421 \\
\hline 113 & $81-36.0$ & $73-00.0$ & 640 \\
\hline 114 & $81-42.3$ & $70-46.0$ & 631 \\
\hline 115 & $81-35.5$ & $67-32.0$ & 567 \\
\hline 116 & $81-02.2$ & $67-07.8$ & 475 \\
\hline 117 & $80-58.1$ & $69-34.0$ & 566 \\
\hline 118 & $81-03.0$ & $72-00.0$ & 588 \\
\hline 122 & $81-08.0$ & $82-05.0$ & 268 \\
\hline 123 & $81-07.0$ & $83-58.0$ & 298 \\
\hline 124 & $80-35.8$ & $83-59.0$ & 315 \\
\hline 125 & $80-00.5$ & $84-01.0$ & 205 \\
\hline 126 & $79-35.5$ & $84-02.0$ & 217 \\
\hline 131 & $80-41.1$ & $82-13.0$ & 202 \\
\hline 134 & $80-36.8$ & $74-32.0$ & 243 \\
\hline 135 & $80-39.9$ & $71-43.0$ & 593 \\
\hline 136 & $80-42.9$ & $69-10.0$ & 549 \\
\hline 137 & $80-45.1$ & $66-49.0$ & 498 \\
\hline 139 & $80-00.0$ & $64-15.0$ & 228 \\
\hline 141 & $80-00.0$ & $66-54.5$ & 520 \\
\hline 142 & $80-00.0$ & $69-47.0$ & 564 \\
\hline 143 & $80-00.0$ & $72-11.0$ & 538 \\
\hline 144 & $80-00.0$ & $74-36.0$ & 215 \\
\hline 147 & $79-34.9$ & $72-00.0$ & 521 \\
\hline 148 & $79-35.0$ & $69-27.0$ & 532 \\
\hline 149 & $79-35.2$ & $66-57.0$ & 526 \\
\hline 151 & $79-06.2$ & $64-06.0$ & 260 \\
\hline 152 & $79-05.5$ & $69-02.0$ & 525 \\
\hline 153 & $79-05.0$ & $74-09.0$ & 366 \\
\hline 154 & $78-37.3$ & $71-41.0$ & 485 \\
\hline 155 & $78-12.6$ & $69-00.0$ & 443 \\
\hline 156 & $78-50.7$ & $66-39.0$ & 374 \\
\hline 157 & $78-33.0$ & $63-38.0$ & 338 \\
\hline
\end{tabular}

TABLE 6.-Station positions and water depths for Edisto-Eastwind (1.967); scdiment samples

\begin{tabular}{rccc}
\hline $\begin{array}{c}\text { Sample } \\
\text { No. }\end{array}$ & $\begin{array}{c}\text { Latitude } \\
(\mathrm{N})\end{array}$ & $\begin{array}{c}\text { Longitude } \\
(\mathrm{E})\end{array}$ & $\begin{array}{c}\text { Depth } \\
\text { (meters) }\end{array}$ \\
\hline 8 & $77-27.6$ & $75-28.0$ & 227 \\
11 & $80-25.0$ & $72-19.0$ & 556 \\
12 & $81-25.2$ & $77-55.5$ & 202 \\
14 & $80-15.7$ & $74-04.4$ & 220 \\
15 & $79-15.2$ & $74-48.0$ & 252 \\
18 & $78-58.8$ & $75-04.0$ & 273 \\
20 & $78-34.5$ & $74-08.5$ & 352 \\
21 & $72-25.7$ & $56-30.5$ & 300 \\
22 & $72-09.0$ & $57-52.4$ & 245 \\
25 & $73-02.1$ & $59-27.0$ & 364 \\
26 & $73-17.0$ & $58-00.0$ & 291 \\
28 & $74-06.0$ & $59-51.0$ & 260 \\
29 & $74-57.0$ & $61-52.0$ & 354 \\
30 & $75-30.5$ & $65-46.0$ & 326 \\
31 & $75-17.2$ & $66-30.0$ & 236 \\
32 & $77-37.0$ & $69-23.0$ & 440 \\
33 & $78-03.0$ & $68-10.0$ & 430 \\
34 & $78-29.0$ & $66-55.0$ & 390 \\
35 & $78-55.0$ & $65-36.0$ & 361 \\
36 & $79-19.0$ & $64-16.0$ & 311 \\
\hline
\end{tabular}




\begin{tabular}{cccc}
\hline $\begin{array}{c}\text { Core } \\
\text { No. }\end{array}$ & $\begin{array}{c}\text { Interval } \\
(\mathrm{cm} .)\end{array}$ & Color & Name \\
\hline $08 \ldots \ldots$ & $0-4.0$ & $5 \mathrm{Y} 4 / 4,10 \mathrm{YR} 4 / 2$, & Clay, sandy, \\
& & $10 \mathrm{YR} 5 / 4$. & silty.
\end{tabular}

$\begin{array}{rrr}4.0-19.0 & 5 \mathrm{Y} 4 / 1 \ldots \ldots & \text { do } \ldots . . \\ 19.0-20.0 & 10 \mathrm{YR} 4 / 2 \ldots & \text { do } \ldots \\ 20.0-38.5 & 5 \mathrm{GY} 4 / 1 \ldots \ldots & \text { do } \ldots . . .\end{array}$

$$
0-9.5
$$

10YR5/4

Clay, silty, foraminiferal.

$9.5-47.5$

12

$$
\begin{array}{r}
0-3.5 \\
3.5-4.5 \\
4.5-6.5
\end{array}
$$

$6.5-18.5$

$18.5-19.5$

$19.5-47.0$

$$
0-4.0
$$

$5 \mathrm{GY} 4 / 1$

$5 Y 4 / 4$

5YR4/1

15

$\begin{array}{lll}0-5.0 & 5 \mathrm{Y} 4 / 4 & \ldots \\ 5.0-9.0 & 5 \mathrm{Y} 5 / 6 \quad \ldots \ldots\end{array}$

$9.0-11.5$

$11.5-28.0$

18

$0-4.5$

$4.5-56.0$

20

$0-4.0$

$5 \mathrm{Y} 4 / 4$

$4.0-26.5$
5GY4/1
$10 \mathrm{YR} 5 / 4$.

5GY $4 / 1$ do

Clay, silty

do
Clay, silty, sandy.

Clay, sandy, silty.

_... do . . . . .

do

do

do ...... do

(n)

lay, sandy, silty.
Clay, silty
Description

Sharp color change with unit below; three slight color changes within unit as indicated. Mottled appearance with lower section brittle.

Homogeneous throughout; worm tubes, little mottling.

Sharp color change with unit above and below; mottled appearance; brittle.

Homogeneous except for slight color gradation at top and mottling by black carbonaceous matter at bottom.

Sharp color change with unit below; spicules and agglutinated tests evident as are worm tubes.

Homogeneous over entire unit; carbonaceous matter in lumps produce black streaks when smeared.

Sharp color change with unit below; worm tubes; three color changes within this unit as indicated; mottled appearance with $4.5-6.5 \mathrm{~cm}$ section having brittle texture.

Homogeneous except for slight color change; some carbonaceous matter.

Sharp color change with units above and below; mottled appearance as in $0-6.5 \mathrm{~cm}$ section.

Mottled with black carbonaceous matter more so towards bottom.

Sharp color change with unit below; color grades from $5 \mathrm{Y} 4 / 4$ to $5 \mathrm{Y} 5 / 6$ within unit; mottled appearance with lower section brittle.

Homogeneous over entire unit; boundary with unit above at angle probably due to corer hitting at angle.

Moderate color change with unit below; quite loosely compact (soupy).

Slight color change with unit below; becomes more compact with depth; black mottling with carbonaceous matter.

Hard, compact, mottled, brittle; sharp color change with unit below.

Homogeneous throughout unit; no carbonaceous mottling.

Sharp color change with unit below; three color changes in this unit as indicated.

Homogeneous throughout unit; worm tubes; carbonaceous mottling which seems to be associated with decomposing worm tubes; earthy odor.

Sharp color change with unit below; color grades from $5 Y 4 / 4$ to $5 Y 5 / 6$; mottled appearance; brittle.

Homogeneous over entire unit; mottled with carbonaceous matter. 
TABLE 7.-Corc descriptions (E-Series)-Continued

\begin{tabular}{|c|c|c|c|c|c|}
\hline & $\begin{array}{l}\text { Core } \\
\text { No. }\end{array}$ & $\begin{array}{c}\text { Interval } \\
(\mathrm{cm} .)\end{array}$ & Color & Name & Description \\
\hline \multirow[t]{6}{*}{21} & -...... & $0-9.5$ & $\begin{array}{l}10 \mathrm{YR} 4 / 2 \\
10 \mathrm{YR} / 4\end{array}$ & $\ldots$ do ........ & Sharp color change with unit below; mottled. \\
\hline & & $9.5-17.0$ & $5 \mathrm{Y} 5 / 2 \ldots \ldots$ & $\ldots$ do .......... & $\begin{array}{l}\text { Distinct from units above and below but } \\
\text { mottled } 10 \mathrm{YR} 4 / 2 \text { to } 5 \mathrm{YR} 4 / 4 \text {; may be dis- } \\
\text { turbed. }\end{array}$ \\
\hline & & $17.0-19.5$ & $\begin{array}{l}5 \mathrm{Y} 4 / 4 \\
10 \mathrm{YR} 4 / 2\end{array}$ & $\ldots . .$. do $\ldots . . .1-1$ & $\begin{array}{l}\text { Moderate color change with units above and } \\
\text { below. }\end{array}$ \\
\hline & & $19.5-35.5$ & $5 \mathrm{Y} 5 / 2 \ldots \ldots$ & $\begin{array}{l}\text { Clay, silty, } \\
\text { sandy. }\end{array}$ & $\begin{array}{l}\text { Homogeneous over most of unit with sections } \\
22-23 \mathrm{~cm} \text { and } 29-30 \mathrm{~cm} \text { somewhat browner. } \\
\text { Possibility of being disturbed. Sandy layer } \\
32.5-33.5 \mathrm{~cm} \text {. }\end{array}$ \\
\hline & & $35.5-38.5$ & $\begin{array}{l}5 \mathrm{Y} 4-4 \\
\quad 10 \mathrm{YR} 4 / 2\end{array}$ & Clay, silty ...... & $\begin{array}{l}\text { Sharp color change with units above and } \\
\text { below; brittle. }\end{array}$ \\
\hline & & $38.5-49.5$ & $5 \mathrm{Y} 4 / 1$ & $\begin{array}{l}\text { Clay, silty, } \\
\text { sandy. }\end{array}$ & $\begin{array}{l}\text { Homogeneous over entire unit except for } \\
\text { sandy layer at } 41-42 \mathrm{~cm} \text {. }\end{array}$ \\
\hline \multirow[t]{2}{*}{22} & $\ldots$ & $0-3.0$ & $5 Y 4 / 4$ & Clay, silty ..... & $\begin{array}{l}\text { Sharp color change with unit below. Not as } \\
\text { brown as surface layers in other cores. }\end{array}$ \\
\hline & & $3.0-59.0$ & $5 \mathrm{G} 4 / 1 \ldots \ldots$ & $\ldots$ do $\ldots . .$. & $\begin{array}{l}\text { Homogeneous over entire unit; mottled with } \\
\text { black carbonaceous matter throughout. }\end{array}$ \\
\hline \multirow[t]{6}{*}{25} & $-\ldots$ & $0-7.5$ & $\begin{array}{l}5 \mathrm{YR} 3 / 2,5 \mathrm{YR} 2 / 2 \\
10 \mathrm{YR} 4 / 2\end{array}$ & $\ldots$ do ........ & $\begin{array}{l}\text { Sharp color change with unit below; three } \\
\text { color changes in this unit as indicated; } \\
\text { lower layers brittle. }\end{array}$ \\
\hline & & $7.5-9.5$ & $5 \mathrm{Y} 5 / 2,5 \mathrm{Y} 4 / 1 \ldots$ & $\ldots$ do $\ldots \ldots$ & $\begin{array}{l}\text { Sharp color change with units above and be- } \\
\text { low; homogeneous. }\end{array}$ \\
\hline & & $9.5-12.0$ & - . n & $\ldots$ do $\ldots . . .$. & $\begin{array}{l}\text { Sharp color change with units above and } \\
\text { below: moderately brittle. }\end{array}$ \\
\hline & & $12.0-15.0$ & $5 \mathrm{Y} 5 / 2$ & do $\ldots . .$. & $\begin{array}{l}\text { Sharp color change with units above and } \\
\text { below; homogeneous. }\end{array}$ \\
\hline & & $15.0-20.5$ & $10 Y R 4 / 2$ & ..... do ..... & $\begin{array}{l}\text { Sharp color change with units above and } \\
\text { below; very brittle. }\end{array}$ \\
\hline & & $20.5-53.0$ & $5 \mathrm{Y} 5 / 2 \ldots \ldots$ & ...... do _.... & Homogeneous over entire unit. \\
\hline \multirow[t]{8}{*}{26} & $-\ldots$. & $0-12.5$ & $\begin{array}{l}10 \mathrm{YR} 4 / 2 \\
5 \mathrm{YR} 3 / 2 \\
10 \mathrm{YR} 5 / 4\end{array}$ & $\ldots$ do $\ldots \ldots$ & $\begin{array}{l}\text { Sharp color change with unit below; three } \\
\text { color changes within unit; lower layer } \\
\text { moderately brittle. }\end{array}$ \\
\hline & & $12.5-18.5$ & $5 \mathrm{Y} 4 / 1$ & $\ldots$ do $\ldots . . .-$ & $\begin{array}{l}\text { Homogeneous over entire unit except for } \\
\text { small brown fragment at } 14-15 \mathrm{~cm} \text {. }\end{array}$ \\
\hline & & $18.5-21.0$ & $10 Y R 5 / 4 \ldots \ldots$ & $\ldots . \ldots$ do $\ldots . .$. & $\begin{array}{l}\text { Sharp color change with units above and } \\
\text { below; moderately brittle. }\end{array}$ \\
\hline & & $21.0-23.0$ & $5 \mathrm{Y} 4 / 1$ & $\ldots$ do $\ldots \ldots$ & Homogeneous over entire unit. \\
\hline & & $23.0-28.5$ & 10YR5/4 & $\ldots$ do $\ldots . .$. & $\begin{array}{l}\text { Moderate color change with units above and } \\
\text { below; brittle lower layer. }\end{array}$ \\
\hline & & $28.5-32.5$ & $5 \mathrm{Y} 4 / 1$ & $\ldots$ do ...... & Homogeneous over entire unit. \\
\hline & & $32.5-37.5$ & $10 \mathrm{YR} / 4$ & $\ldots$ do $\ldots \ldots$ & $\begin{array}{l}\text { Moderate color change with units above and } \\
\text { below. Moderately brittle. }\end{array}$ \\
\hline & & $37.5-47.0$ & $5 \mathrm{Y} 4 / 1$ & $\ldots$ do $\ldots . . . .$. & Homogeneous over entire unit. \\
\hline \multirow[t]{2}{*}{28} & $-\ldots$ & $0-19.5$ & $10 Y R 4 / 2 \ldots \ldots$ & $\begin{array}{l}\text { Clay, silty, } \\
\text { sandy. }\end{array}$ & $\begin{array}{l}\text { Slight color variation to } 5 \mathrm{YR} 4 / 4 \text { at about } \\
8 \mathrm{~cm} \text {. }\end{array}$ \\
\hline & & $19.5-25.5$ & $5 Y 4 / 1 \ldots \ldots$ & $\begin{array}{l}\text { Clay, silty, } \\
\text { sandy, gravel. }\end{array}$ & $\begin{array}{l}\text { Sharp color change and textural change with } \\
\text { unit above. Quite dry and brittle. }\end{array}$ \\
\hline \multirow[t]{5}{*}{29} & -. - & $0-17.0$ & $\begin{array}{l}10 \mathrm{YR} 4 / 2 \\
5 \mathrm{YR} 3 / 2\end{array}$ & $\begin{array}{l}\text { Clay, silty, } \\
\text { sandy. }\end{array}$ & $\begin{array}{l}\text { Moderate color change with unit below. } \\
\text { Mottled with } 5 \mathrm{YR} 3 / 2 \text {. }\end{array}$ \\
\hline & & $17.0-18.5$ & $5 \mathrm{YR} 4 / 1 \ldots \ldots$ & ..... do _..... & Homogeneous over entire unit. \\
\hline & & $18.5-22.0$ & $5 \mathrm{YR} 4 / 2 \ldots \ldots$ & Clay, silty _..... & $\begin{array}{l}\text { Sharp color change with units above and } \\
\text { below; moderately brittle. }\end{array}$ \\
\hline & & $22.0-23.5$ & $5 \mathrm{YR} 4 / 1 \ldots$ & ...... do _..... & Homogeneous over entire unit. \\
\hline & & $23.5-28.5$ & $5 \mathrm{YR} 4 / 2 \ldots \ldots$ & $\ldots \ldots$ do $\ldots . . .$. & $\begin{array}{l}\text { Sharp color change with units above and } \\
\text { below; moderately brittle. }\end{array}$ \\
\hline
\end{tabular}


TABLF, 7.-Corc descriptions (E-Series)-Continued

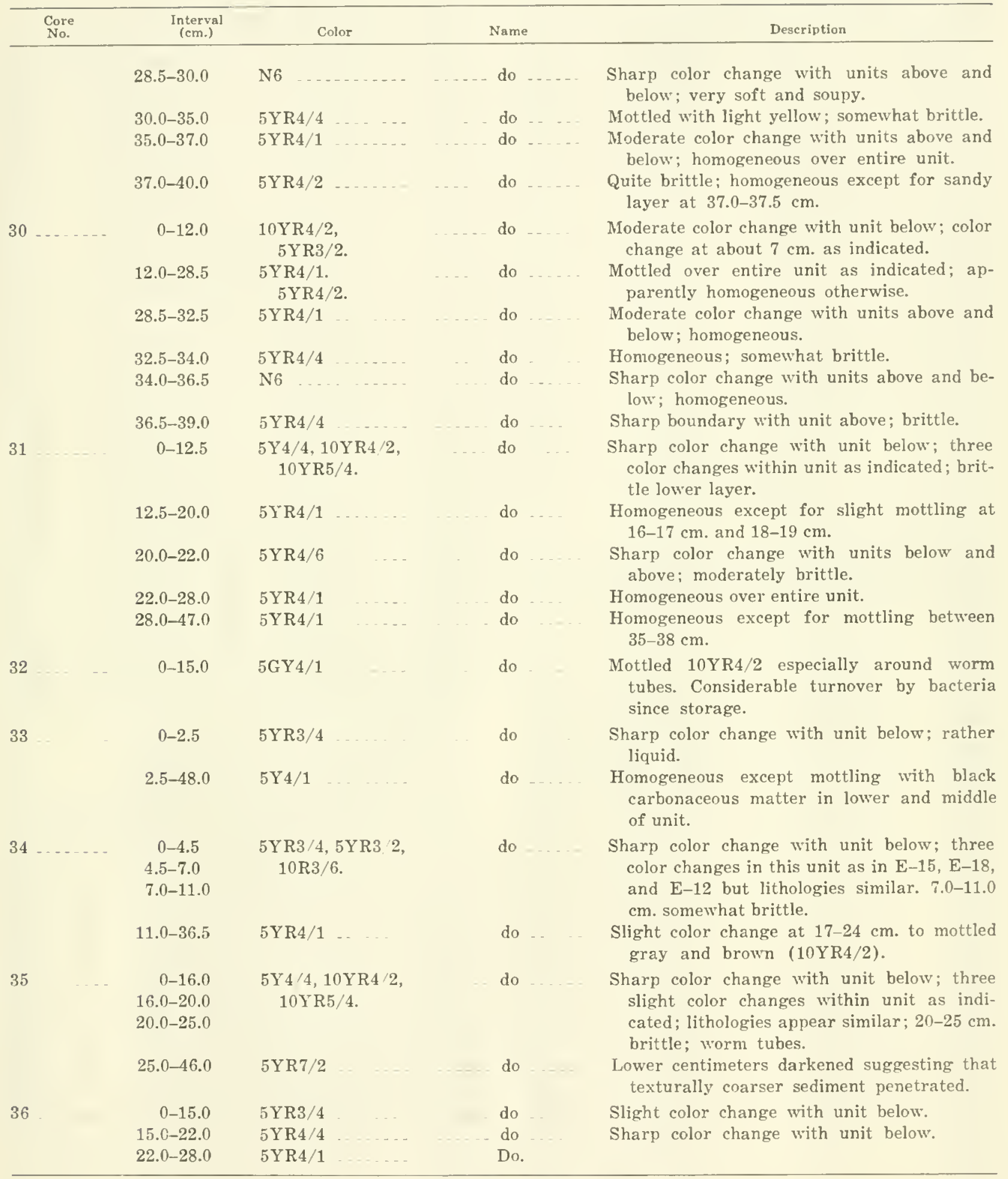




\begin{tabular}{|c|c|c|c|c|c|c|c|c|c|c|c|c|c|c|}
\hline & $\begin{array}{l}\text { Core } \\
\text { No. }\end{array}$ & $\begin{array}{c}\text { Interval } \\
(\mathrm{cm} .)\end{array}$ & Gravel & Sand & Silt & Clay & & $\begin{array}{l}\text { Core } \\
\text { No. }\end{array}$ & $\begin{array}{c}\text { Interval } \\
\text { (cm.) }\end{array}$ & Gravel & \multicolumn{2}{|c|}{ Sand } & Silt & Clay \\
\hline E-8 & - . . . - - & $0-1$ & & 8.60 & 50.00 & 41.30 & E-26 & . & $25-28$ & & \multicolumn{2}{|c|}{7.50} & 24.12 & 68.38 \\
\hline E-8 & $\ldots$ & $2-5$ & & 8.02 & 38.80 & 53.18 & E-26 & $\ldots$ & $28-31$ & & \multicolumn{2}{|c|}{9.82} & 23.30 & 66.88 \\
\hline E-8 & $\ldots . .$. & $5-7$ & & 10.20 & 53.30 & 36.50 & $\mathrm{E}-26$ & $\ldots$ & $31-34$ & & \multicolumn{2}{|c|}{7.00} & 22.79 & 70.21 \\
\hline E-8 & $\ldots$ & $11-13$ & & 15.60 & 43.10 & 41.30 & E-26 & - . . . - & $34-37$ & & \multicolumn{2}{|c|}{8.24} & 24.60 & 67.16 \\
\hline E-8 & . - . - . & $15-17$ & & 16.70 & 42.80 & 40.50 & E-26 & $\ldots$ & $37-40$ & & \multicolumn{2}{|c|}{8.29} & 23.65 & 68.06 \\
\hline E-8 - & - _. & $20-22$ & & 18.80 & 39.60 & 41.60 & E-26 & $\ldots$ & $40-43$ & & \multicolumn{2}{|c|}{11.14} & 24.60 & 64.26 \\
\hline E-8 & 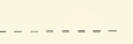 & $25-27$ & & 15.00 & 41.90 & 43.10 & E-26 & $\ldots$ & $43-47$ & & \multicolumn{2}{|c|}{14.47} & 27.84 & 57.79 \\
\hline E-8 & $\ldots$ & $31-33$ & & 11.20 & 45.50 & 43.20 & E-28 & $\ldots \ldots$ & $0-3$ & & \multicolumn{2}{|c|}{6.83} & 26.17 & 67.00 \\
\hline E-8 & - . - - - & $39-42$ & & 6.10 & 45.60 & 48.40 & E-28 & - _ - & $10-13$ & & \multicolumn{2}{|c|}{5.68} & 23.82 & 70.50 \\
\hline E-11 & - . - . - & $0-2$ & & 2.70 & 45.90 & 51.40 & E-28 & - . . . . - & $20-23$ & 4.48 & \multicolumn{2}{|c|}{19.26} & 33.69 & 42.57 \\
\hline E-11 & $\ldots$ & $2-7$ & & 2.00 & 40.53 & 57.47 & E-28 & $\ldots$ & $23-26$ & 3.67 & \multicolumn{2}{|c|}{16.92} & 40.99 & 38.42 \\
\hline E-11 & $\ldots$ & $6-8$ & & 1.80 & 41.50 & 56.60 & E-29 & - . . & $0-3$ & & \multicolumn{2}{|c|}{4.90} & 30.64 & 64.46 \\
\hline E-11 & $\ldots \ldots$ & 11-13 & & 2.40 & 36.60 & 61.00 & $\mathrm{E}-29$ & $\ldots$ & $7.5-10.5$ & & & .22 & 28.61 & 69.17 \\
\hline E-11 & $\ldots$ & $15-17$ & & 3.60 & 38.60 & 57.80 & E-29 & $\ldots \ldots$ & $19-22$ & & & .46 & 24.32 & 74.22 \\
\hline E-11 & $\ldots$ & $21-23$ & & 2.90 & 37.20 & 60.00 & E-29 & $\ldots$ & 29-32 & & & .17 & 20.94 & 77.89 \\
\hline E-11 & - . - - - & $25-27$ & & 6.90 & 34.40 & 58.60 & E-30 & . . . . & $0-3$ & & & .89 & 30.78 & 65.33 \\
\hline E-11 & $\ldots$ & $31-32$ & & 7.20 & 36.20 & 56.60 & E-30 & $\ldots$ & $7.5-11.5$ & & & .61 & 25.34 & 73.05 \\
\hline E-11 & $\ldots$ & $35-37$ & & 5.30 & 34.70 & 59.90 & E-30 & - . & $20-23$ & & & .75 & 23.29 & 75.96 \\
\hline E-11 & . - - - - & 41.43 & & 11.30 & 41.30 & 47.40 & E-30 & - . . . & $30-33$ & & & .74 & 20.05 & 79.21 \\
\hline E-12 & $2 \ldots$ & $0-5$ & & 3.32 & 49.52 & 47.16 & $E-30$ & - . . . & $36.5-40$ & & & .67 & 23.87 & 74.46 \\
\hline E-14 & $\ldots \ldots$ & $0-4$ & 3.62 & 35.03 & 33.68 & 27.67 & E-31 & . . . . & $0-3$ & & & .14 & 38.00 & 57.86 \\
\hline E-15 & $\ldots$ & $0-4$ & & 33.47 & 25.56 & 40.97 & E-31 & $\ldots$ & $8.5-11.5$ & & & .54 & 27.04 & 70.42 \\
\hline E-18 & . . . - . & $0-4$ & & 4.21 & 39.11 & 56.68 & $\mathrm{E}-31$ & . . . . & $20-23$ & & & .40 & 24.09 & 72.51 \\
\hline E-20 & $\ldots$ & $0-4$ & & 8.59 & 40.95 & 50.46 & $E-31$ & - . . - . & $30-33$ & & & .00 & 24.49 & 72.51 \\
\hline E-21 & $\ldots \ldots$ & $0-3$ & & 7.74 & 36.22 & 56.04 & $E-31$ & - . . . & $40-43$ & & & .29 & 22.30 & 74.41 \\
\hline E-21 & $\ldots \ldots$ & 3-7 & & 5.39 & 33.45 & 61.16 & E-32 & - . . . & $0-5$ & & & .17 & 45.96 & 49.87 \\
\hline E-21 & . - . & $14-17$ & & 6.57 & 25.82 & 67.61 & E-33 & - & $0-4$ & & & .19 & 41.07 & 51.74 \\
\hline E-21 & . . . - & $17-20$ & & 5.77 & 27.26 & 66.97 & E-34 & $\ldots$ & $0-5$ & & & 32 & 41.66 & 56.02 \\
\hline E-21 & $\ldots$ & $20-23$ & & 5.49 & 27.16 & 67.35 & E-35 & & $0-5$ & & & .93 & 23.18 & 74.89 \\
\hline E-21 & $\ldots$ & $32-36$ & & 18.01 & 25.91 & 56.08 & $\mathrm{E}-36$ & & $0-5$ & & & .03 & 44.29 & 50.68 \\
\hline E-21 & $\ldots$ & $36-39$ & & 11.40 & 24.35 & 64.25 & & & & & & & & \\
\hline $\mathrm{E}-21$ & L . . . . & $39-42$ & & 22.02 & 23.07 & 54.91 & & & & & & & & \\
\hline E-22 & . . . . . & $0-2$ & & 4.91 & 37.72 & 57.37 & & & & & & & & \\
\hline $\mathrm{E}-22$ & . & $10-12$ & & 4.83 & 30.38 & 64.79 & & & ABLE $9 .-T$ & 'extural & l para & ameter & & \\
\hline E-22 & 2. - . - & $20-22$ & & 4.82 & 29.88 & 65.30 & & & & & & & & \\
\hline E-22 & , - . . . & $31-33$ & & 6.63 & 27.38 & 66.12 & & $\begin{array}{l}\text { Core } \\
\text { No. }\end{array}$ & $\begin{array}{c}\text { Interval } \\
(\mathrm{cm} .)\end{array}$ & Median & Mean & $\begin{array}{c}\text { Standar } \\
\text { dev. }\end{array}$ & $\begin{array}{c}\text { Skew- } \\
\text { ness }\end{array}$ & $\begin{array}{l}\text { Kurto- } \\
\text { sis }\end{array}$ \\
\hline $\begin{array}{l}\mathrm{E}-22 \\
\mathrm{E}-22\end{array}$ & , & $\begin{array}{l}40-42 \\
51-53\end{array}$ & & $\begin{array}{l}4.63 \\
9.91\end{array}$ & $\begin{array}{l}29.41 \\
27.62\end{array}$ & 62.47 & $\mathrm{E}-8$ & $\ldots$ & $2-5$ & 8.20 & 8.03 & 3.00 & -0.03 & 0.90 \\
\hline E-25 & F & $0-3$ & & 3.41 & 30.84 & 65.75 & $\mathrm{E}-11$ & ..... & $2-7$ & 8.55 & 8.58 & 2.72 & 0.05 & 0.93 \\
\hline E-25 & $5 \ldots$ & $3-10$ & & 1.92 & 25.68 & 72.35 & E-12 & - . . . & $0-5$ & 7.80 & 7.97 & 2.60 & 0.13 & 091 \\
\hline E-25 & $5 \ldots$ & $10-13$ & & 2.28 & 23.33 & 74.39 & $\mathrm{E}-14$ & & $0-4$ & 4.60 & 5.70 & 333 & 0.47 & 0.87 \\
\hline $\mathrm{E}-25$ & ; ...... & $13-15$ & & 1.61 & 21.88 & 76.45 & E-15 & - . . . _ & $0-5$ & 7.00 & 6.97 & 3.40 & 007 & 0.72 \\
\hline $\mathrm{E}-25$ & $5 \ldots$ & 15-19 & & 1.42 & 26.50 & 72.08 & E-18 & - . . & $0-4$ & 8.40 & 8.40 & 2.73 & 0.01 & 1.00 \\
\hline E-25 & ; ..... & $19-22$ & & 1.82 & 24.17 & 74.01 & $\mathrm{E}-20$ & . . . . & $0-4$ & 8.00 & 7.87 & 2.73 & -0.05 & 1.03 \\
\hline E-25 & $5 \ldots$ & $22-30$ & & 2.03 & 23.79 & 74.18 & $\mathrm{E}-21$ & $\ldots$ & $0-3$ & 8.35 & 8.10 & 269 & -0.16 & 1.10 \\
\hline E-25 & $5 \ldots . .$. & $30-33$ & & 2.56 & 22.19 & 75.25 & E-21 & $\ldots$ & $3-7$ & 8.65 & 8.47 & 2.63 & -0.12 & 1.01 \\
\hline E-25 & $5 \ldots$ & $33-40$ & & 1.90 & 23.70 & 74.40 & E-21 & $\ldots$ & 14-17 & 9.25 & 8.97 & 3.37 & -0.10 & 0.96 \\
\hline $\mathrm{E}-25$ & $5 \ldots \ldots$ & $40-43$ & & 2.23 & 20.31 & 72.46 & $\mathrm{E}-21$ & ...... & $17-20$ & 9.20 & 9.03 & 3.14 & -0.07 & 1.02 \\
\hline E-25 & $5 \ldots$ & $43-50$ & & 1.93 & 23.18 & 74.89 & E-21 & . & $20-23$ & 9.25 & 9.07 & 3.12 & -0.07 & 1.03 \\
\hline $\mathrm{E}-25$ & $5 \ldots \ldots$ & $50-54$ & & 2.18 & 21.92 & 75.90 & $E-21$ & . . . . & $32-36$ & 8.55 & 8.08 & 388 & -0.10 & 0.81 \\
\hline E-26 & $6 \ldots$ & $0-3$ & 1.41 & 7.45 & 29.74 & 61.40 & E-21 & . . . . & $36-39$ & 9.20 & 8.67 & 352 & -0.18 & 0.96 \\
\hline E-26 & $6 \ldots$ & $3-7$ & & 5.46 & 32.13 & 62.41 & $\mathrm{E}-21$ & $\ldots$ & $39-42$ & 8.45 & 7.72 & 396 & -0.18 & 0.77 \\
\hline E-26 & $6 \ldots$ & $7-10$ & & 5.40 & 29.08 & 65.52 & $\mathrm{E}-22$ & $\ldots$ & $0-2$ & 8.45 & 8.20 & 2.91 & -0.06 & 0.96 \\
\hline E-26 & $6 \quad \ldots-\ldots$ & $10-13$ & & 7.30 & 29.80 & 62.90 & E-22 & $\ldots$ & $10-12$ & 9.15 & 9.05 & 3.10 & -0.03 & 1.06 \\
\hline E-26 & $6 \ldots$ & $13-16$ & 1.80 & 8.58 & 24.82 & 64.80 & E-22 & $2 \ldots$ & $20-22$ & 9.00 & 9.17 & 3.17 & 0.07 & 1.00 \\
\hline E-26 & $6 \ldots$ & $16-19$ & & 7.27 & 25.46 & 67.27 & E-22 & $\ldots$ & $31-33$ & 9.10 & 8.75 & 3.18 & -0.13 & 1.05 \\
\hline $\mathrm{E}-26$ & $6 \ldots$ & $19-22$ & & 8.82 & 23.96 & 67.22 & $\mathrm{E}-22$ & 2..... & $40-42$ & 9.15 & 9.22 & 3.02 & 0.02 & 1.03 \\
\hline $\mathrm{E}-26$ & $6 \ldots \ldots$ & $22-25$ & & 7.46 & 24.47 & 68.07 & E-22 & $\ldots$ & $51-53$ & 9.10 & 8.65 & 3.41 & -0.16 & 1.06 \\
\hline
\end{tabular}


TABle 9.-Continued

\begin{tabular}{|c|c|c|c|c|c|c|c|}
\hline & $\begin{array}{l}\text { Core } \\
\text { No. }\end{array}$ & $\begin{array}{c}\text { Interval } \\
\text { (cm.) }\end{array}$ & Median & Mean & $\begin{array}{l}\text { Standard } \\
\text { dev. }\end{array}$ & $\begin{array}{c}\text { d Skew- } 1 \\
\text { ness }\end{array}$ & $\begin{array}{l}\text { Kurto- } \\
\text { sis }\end{array}$ \\
\hline $\mathrm{E}-25$ & - . - - - & $0-3$ & 8.95 & 8.88 & 2.22 & -0.10 & 1.18 \\
\hline $\mathrm{E}-25$ & $\ldots$ & $3-10$ & 9.30 & 9.23 & 2.19 & -0.10 & 1.19 \\
\hline E-25 & .... - & $10-13$ & 9.50 & 9.55 & 2.44 & 0.02 & 1.02 \\
\hline E-25 & - . - - & $13-15$ & 9.45 & 9.53 & 2.26 & -0.00 & 1.12 \\
\hline $\mathrm{E}-25$ & $\ldots \ldots$ & $15-19$ & 9.15 & 9.22 & 2.07 & -0.02 & 1.12 \\
\hline E-25 & . . . . - & $19-22$ & 9.70 & 9.72 & 2.63 & -0.00 & 1.00 \\
\hline E-25 & $\ldots$ & $22-30$ & 9.40 & 9.43 & 2.16 & -0.02 & 1.08 \\
\hline E-25 & $\ldots \ldots$ & $30-33$ & 9.85 & 9.85 & 2.84 & -0.02 & 1.05 \\
\hline E-25 & $\ldots$ & $33-40$ & 9.45 & 9.48 & 2.14 & 0.02 & 0.98 \\
\hline E-25 & . . . - & $40-43$ & 9.75 & 9.80 & 2.47 & -0.01 & 1.08 \\
\hline E-25 & . . . . & $43-50$ & 9.70 & 9.73 & 2.42 & -0.00 & 1.02 \\
\hline E-25 & . . . . & $50-54$ & 9.80 & 9.87 & 2.57 & 0.00 & 1.02 \\
\hline $\mathrm{E}-26$ & $\ldots \ldots$ & $0-3$ & 8.70 & 8.40 & 285 & -0.20 & 1.29 \\
\hline $\mathrm{E}-26$ & $\ldots \ldots$ & $3-7$ & 8.70 & 8.52 & 2.64 & -0.12 & 1.09 \\
\hline E-26 & $\ldots$ & $7-10$ & 9.10 & 8.85 & 2.72 & -0.14 & 1.09 \\
\hline E-26 & $\ldots$ & $10-13$ & 9.40 & 8.40 & 3.18 & -0.02 & 1.19 \\
\hline E-26 & ..... & $13-15$ & 9.30 & 8.73 & 3.59 & -0.20 & 1.16 \\
\hline $\mathrm{E}-26$ & $\ldots$. & $15-19$ & 9.40 & 9.18 & 3.08 & -0.14 & 1.15 \\
\hline $\mathrm{E}-26$ & $\ldots . .$. & $19-22$ & 9.35 & 8.93 & 3.31 & -0.18 & 1.15 \\
\hline E-26 & $\ldots \ldots$ & $22-25$ & 9.30 & 8.90 & 3.23 & -0.17 & 1.12 \\
\hline $\mathrm{E}-26$ & - . . . & $25-28$ & 9.20 & 8.90 & 3.14 & -0.14 & 1.11 \\
\hline $\mathrm{E}-26$ & $\ldots \ldots$ & $28-31$ & 9.10 & 8.58 & 3.39 & -0.19 & 1.10 \\
\hline $\mathrm{E}-26$ & $\ldots$. & $31-34$ & 9.40 & 8.97 & 3.11 & -0.19 & 1.12 \\
\hline $\mathrm{E}-26$ & $\ldots \ldots$ & $34-37$ & 9.20 & 8.73 & 3.34 & -0.16 & 1.09 \\
\hline E-26 & $\ldots \ldots$ & $37-40$ & 9.25 & 8.72 & 3.36 & -0.18 & 1.03 \\
\hline $\mathrm{E}-26$ & - - - & $40-43$ & 9.15 & 8.48 & 3.42 & -0.22 & 0.88 \\
\hline E-26 & - . - - - & $43-47$ & 8.55 & 8.17 & 3.61 & -0.09 & 0.77 \\
\hline E-28 & $\ldots$ & $0-3$ & 9.40 & 8.93 & 2.59 & -0.31 & 1.29 \\
\hline E-28 & $\ldots$ & $10-13$ & 9.35 & 9.10 & 2.68 & -0.18 & 1.16 \\
\hline E-28 & $\ldots$ & $20-23$ & 7.00 & 6.90 & 4.25 & -0.07 & 1.01 \\
\hline E-28 & . . . . & $23-26$ & 6.70 & 6.97 & 3.91 & 0.05 & 1.03 \\
\hline E-29 & .... . . & $0-3$ & 8.70 & 865 & 2.37 & -0.08 & 1.21 \\
\hline E-29 & .... & $7.5-10.5$ & 9.00 & 8.88 & 2.24 & -0.09 & 1.07 \\
\hline E-29 & - . . - & $19-22$ & 9.40 & 9.32 & 2.25 & -0.08 & 1.13 \\
\hline E-29 & . . . . . & $29-32$ & 9.60 & 9.62 & 2.26 & -0.02 & 1.10 \\
\hline $\mathrm{E}-30$ & . . . . & $0-3$ & 8.80 & 8.83 & 2.14 & -0.06 & 1.19 \\
\hline E-30 & . . . . - & $7.5-11.5$ & 9.50 & 9.53 & 2.48 & 0.01 & 1.01 \\
\hline E-30 & $\ldots$ & $20-23$ & 9.50 & 9.50 & 2.35 & -0.02 & 1.06 \\
\hline E-30 & .... - & $30-33$ & 9.75 & 9.80 & 2.40 & 0.01 & 1.08 \\
\hline E-30 & $\ldots \ldots$ & $36.5-40$ & 9.60 & 9.60 & 2.48 & -0.03 & 1.05 \\
\hline E-31 & . . . . & 0-3 & 8.45 & 8.42 & 2.37 & -0.07 & 1.10 \\
\hline E-31 & . . . . & $8.5-11.5$ & 9.20 & 9.10 & 2.56 & -0.06 & 1.06 \\
\hline $\mathrm{E}-31$ & . . . . & $20-23$ & 9.55 & 9.35 & 2.85 & -0.10 & 1.07 \\
\hline E-31 & - . . . & $30-33$ & 9.60 & 9.43 & 2.77 & -0.11 & 1.06 \\
\hline E-31 & $-\ldots \ldots$ & $40-43$ & 9.55 & 9.42 & 2.53 & -0.14 & 1.16 \\
\hline E-32 & $\ldots .$. & $0-5$ & 7.95 & 8.02 & 2.97 & 0.10 & 0.84 \\
\hline E-33 & . . . . . & $0-4$ & 8.10 & 8.33 & 3.16 & 0.06 & 0.9 \\
\hline E-34 & ..... & $0-5$ & 8.40 & 8.50 & 2.44 & 0.07 & 0.99 \\
\hline E-35 & .... & $0-5$ & 8.35 & 8.28 & 3.07 & 0.07 & 0.86 \\
\hline E-36 & ..... & $0-5$ & 8.10 & 8.08 & 2.96 & 0.05 & 0.88 \\
\hline
\end{tabular}

TABLE 10,-X-ray diffraction data for (1) black crusts from corc E-26, 3-7, cm. and (2) brown earthy substance from core $E-26,7-10 \mathrm{~cm}$

\begin{tabular}{|c|c|c|c|}
\hline $\begin{array}{c}\text { Observed } \\
\text { pattern }\end{array}$ & $\begin{array}{c}\text { Observed } \\
\text { intensity } \\
\text { (1) }\end{array}$ & $\begin{array}{l}\text { Observed } \\
\text { pattern }\end{array}$ & $\begin{array}{l}\text { Observed } \\
\text { intensity } \\
\text { (2) }\end{array}$ \\
\hline$\ldots \ldots$ & M & 5.52 & $W(d)$ \\
\hline $4.28 \quad \ldots$ & VW & 4.58 & M \\
\hline $3.62 \ldots \ldots$ & VVW (b) & 4.25 & $M(b)$ \\
\hline $3.37 \ldots \ldots$ & S & 3.35 & $\mathbf{S}$ \\
\hline $3.18 \ldots \ldots$ & VVW & 3.18 & W \\
\hline $2.95 \ldots \ldots$ & VVW & 2.96 & M \\
\hline $2.50 \ldots \ldots$ & M & 2.80 & MS \\
\hline $2.26 \ldots \ldots$ & $\mathrm{W}^{(\mathrm{b})}$ & 2.59 & $\operatorname{MS}^{(b)}$ \\
\hline $2.16 \ldots \ldots$ & VVW & 2.39 & M \\
\hline $1.97 \ldots \ldots$ & VVW & 2.30 & W \\
\hline $1.82 \ldots$ & M & 2.11 & $w^{(b)}$ \\
\hline $1.65 \ldots \ldots$ & $V V W^{(b)}$ & 1.99 & $\mathrm{~W}$ \\
\hline $1.54 \ldots \ldots$ & VW & 1.82 & M \\
\hline $1.43 \ldots \ldots$ & W & 1.67 & VW \\
\hline $1.42 \ldots \ldots$ & $\mathbf{M}^{(b)}$ & 1.61 & VW \\
\hline $1.38 \ldots \ldots$ & M & 1.55 & W \\
\hline $1.295 \ldots \ldots$ & VVW & 1.50 & W \\
\hline $1.225 \ldots \ldots$ & VVW & 1.38 & M \\
\hline \multirow[t]{3}{*}{1.180} & VVW & 1.295 & VW \\
\hline & & 1.195 & $V W$ \\
\hline & & 1.05 & VVW \\
\hline
\end{tabular}

NoTE.- " $d$ " and "b" represent diffuse and broad peaks; VVW, VW, W, M, MS, S are very very weak, very weak, weak, medium, medium strong, very strong intensities respectively. 
TABLE 11.-Comparison of X-ray data for pellets separated from core $E-31,20-23 \mathrm{~cm}$. with data for the mineral vivianite

\begin{tabular}{|c|c|c|c|}
\hline \multirow{2}{*}{$\begin{array}{l}\text { Observed } \\
\text { pattern }\end{array}$} & \multirow{2}{*}{$\begin{array}{l}\text { Observed } \\
\text { intensity }\end{array}$} & \multicolumn{2}{|c|}{$\begin{array}{c}\text { Vivianite } \\
\text { (ASTM No. 3-0070) }\end{array}$} \\
\hline & & $d A$ & $I / I_{1}$ \\
\hline$\ldots \ldots$ & M & 8.00 & 27 \\
\hline $6.78 \ldots$ & VS & 6.80 & 100 \\
\hline 4.91 & M & 4.91 & 40 \\
\hline$\ldots . .$. & $\mathrm{W}$ & 4.50 & 13 \\
\hline . . . . . & W & 4.32 & 4 \\
\hline $4.07 \ldots$ & VW & 4.09 & 13 \\
\hline $3.85 \quad \ldots \ldots$ & M & 3.84 & 40 \\
\hline$\ldots \ldots$ & $\ldots$ & 3.65 & 5 \\
\hline $3.35 \ldots \ldots$ & M & 3.33 & 3 \\
\hline$\ldots \ldots$ & M & 3.20 & 53 \\
\hline$\ldots \ldots \ldots$ & $\mathrm{S}$ & 2.97 & 67 \\
\hline$\ldots \ldots$ & $\mathrm{S}$ & 2.71 & 67 \\
\hline$\ldots . .$. & VW & 2.64 & 8 \\
\hline$\ldots \ldots$ & M & 2.52 & 33 \\
\hline$\ldots \ldots$ & $\mathbf{M}$ & 2.42 & 40 \\
\hline$\ldots \ldots$ & W & 2.31 & 27 \\
\hline$\ldots \ldots$ & W & 2.23 & 20 \\
\hline $2.18 \ldots \ldots$ & W & 2.19 & 20 \\
\hline $2.07 \ldots$ & W & 2.07 & 23 \\
\hline - & $\ldots$ & 2.01 & 8 \\
\hline - & $\ldots$ & 1.96 & 8 \\
\hline $1.93 \ldots$ & W & 1.92 & 33 \\
\hline $1.91 \ldots$ & W & 1.89 & 20 \\
\hline $1.82 \ldots \ldots$ & VW & 1.82 & 11 \\
\hline $1.77 \ldots$ & VW & 1.78 & 13 \\
\hline $1.68 \ldots$ & W & 1.67 & 40 \\
\hline $1.58 \ldots \ldots$ & W & 1.59 & 23 \\
\hline - . . . . . . & $\ldots$ & 1.55 & 7 \\
\hline$\ldots$ & $\ldots$ & 1.52 & 11 \\
\hline - . & $\ldots$ & 1.49 & 12 \\
\hline - & - - - - & 1.47 & 7 \\
\hline
\end{tabular}

TABLE 12.-Distribution of iron and manganese in eore $E-26$

\begin{tabular}{|c|c|c|c|c|}
\hline $\begin{array}{l}\text { Core } \\
\text { No. }\end{array}$ & $\begin{array}{c}\text { Interval } \\
(\mathrm{cm})\end{array}$ & $\begin{array}{c}\mathrm{Fe} \\
\text { (weight } \\
\text { percent) }\end{array}$ & $\begin{array}{c}M n \\
\text { (weimht } \\
\text { percent) }\end{array}$ & $\mathrm{Mn} / \mathrm{Fe}$ \\
\hline \multirow[t]{31}{*}{ E-26 } & $0-1$ & 1.19 & 0.82 & 0.69 \\
\hline & $1-2$ & 1.24 & 0.94 & 0.76 \\
\hline & $2-3$ & 1.19 & 2.45 & 2.06 \\
\hline & $3-4$ & 1.12 & 6.20 & 5.54 \\
\hline & $4-5$ & 1.24 & 2.35 & 1.90 \\
\hline & $5-6$ & 1.23 & 2.45 & 1.99 \\
\hline & $6-7$ & 1.24 & 3.20 & 2.58 \\
\hline & $7-8$ & 2.65 & 1.65 & 0.62 \\
\hline & $8-9$ & 4.50 & 0.15 & 0.03 \\
\hline & $9-10$ & 3.20 & 0.12 & 0.04 \\
\hline & $10-11$ & 0.80 & 0.06 & 0.08 \\
\hline & $11-12$ & 0.72 & 0.05 & 0.07 \\
\hline & $12-13$ & 0.78 & 0.04 & 0.05 \\
\hline & $13-14$ & 0.32 & 0.04 & 0.12 \\
\hline & $14-15$ & 0.62 & 0.07 & 0.11 \\
\hline & $15-16$ & 0.66 & 0.04 & 0.06 \\
\hline & $16-17$ & 0.38 & 0.03 & 0.08 \\
\hline & $17-18$ & 0.52 & 0.15 & 0.29 \\
\hline & $18-19$ & 1.20 & 0.26 & 0.22 \\
\hline & $19-20$ & 1.55 & 0.34 & 0.22 \\
\hline & $20-21$ & 1.50 & 0.30 & 0.20 \\
\hline & $22-23$ & 0.59 & 0.16 & 0.27 \\
\hline & $23-24$ & 1.95 & 0.31 & 0.16 \\
\hline & $25-26$ & 1.67 & 0.24 & 0.14 \\
\hline & $27-28$ & 1.67 & 0.12 & 0.07 \\
\hline & $29-30$ & 0.64 & 0.04 & 0.06 \\
\hline & $30-31$ & 0.49 & 0.04 & 0.08 \\
\hline & $34-35$ & 1.75 & 0.10 & 0.06 \\
\hline & $36-37$ & 1.35 & 0.08 & 0.06 \\
\hline & $45-46$ & 0.32 & 0.02 & 0.06 \\
\hline & $46-47$ & 0.32 & 0.03 & 0.09 \\
\hline
\end{tabular}


TABLE 13.-Distribution of iron and manganese in core $N-148$

\begin{tabular}{ccccc}
\hline $\begin{array}{c}\text { Core } \\
\text { No. }\end{array}$ & $\begin{array}{c}\text { Sinterval } \\
\text { (cm) }\end{array}$ & $\begin{array}{c}\text { Fe } \\
\text { (weight } \\
\text { percent) }\end{array}$ & $\begin{array}{c}\text { Mn } \\
\text { (weight } \\
\text { percent) }\end{array}$ & Mn/Fe \\
\hline N-148 & $0-1$ & 1.46 & 0.43 & 0.29 \\
& $1-2$ & 1.53 & 0.51 & 0.33 \\
& $2-3$ & 1.50 & 0.54 & 0.36 \\
$3-4$ & 1.48 & 0.78 & 0.53 \\
& $4-5$ & 1.52 & 1.25 & 0.82 \\
$5-6$ & 1.50 & 2.10 & 1.40 \\
& $6-7$ & 1.41 & 1.85 & 1.31 \\
$7-8$ & 1.45 & 1.45 & 1.00 \\
$8-9$ & 1.39 & 1.23 & 0.88 \\
$9-10$ & 1.76 & 1.58 & 0.90 \\
$10-11$ & 5.45 & 0.36 & 0.07 \\
$11-12$ & 3.45 & 0.25 & 0.07 \\
$12-13$ & 3.55 & 0.23 & 0.06 \\
$13-14$ & 2.65 & 0.36 & 0.14 \\
$14-15$ & 2.00 & 0.35 & 0.18 \\
$15-16$ & 1.50 & 0.23 & 0.15 \\
$16-17$ & 0.99 & 0.38 & 0.38 \\
$17-18$ & 1.02 & 0.25 & 0.23 \\
$18-19$ & 0.98 & 0.23 & 0.24 \\
$19-20$ & 0.87 & 0.18 & 0.21 \\
& $20-21$ & 0.31 & 0.04 & 0.13 \\
$30-31$ & 0.48 & 0.01 & 0.02 \\
$40-41$ & 0.73 & 0.01 & 0.01 \\
$43.5-44.5$ & 1.47 & 0.01 & 0.01 \\
\hline & & &
\end{tabular}

TABLE 14.-Nondetrital iron and manganese in surface sediments

\begin{tabular}{|c|c|c|c|c|c|}
\hline & $\begin{array}{l}\text { Core } \\
\text { No. }\end{array}$ & $\begin{array}{c}\text { Interval } \\
(\mathrm{cm})\end{array}$ & $\begin{array}{c}\mathrm{Fe} \\
\text { (weight } \\
\text { percent) }\end{array}$ & $\begin{array}{c}\mathrm{Mn} \\
\text { (weight } \\
\text { percent) }\end{array}$ & $\mathrm{Mn} / \mathrm{Fe}$ \\
\hline E-8 & . . . . & $0-1$ & 1.76 & 0.30 & 0.17 \\
\hline E-11 & & $0-1$ & 1.45 & 0.18 & 0.12 \\
\hline E-12 & & $0-1$ & 1.22 & 0.28 & 0.23 \\
\hline E-14 & ....... & $0-1$ & 1.04 & 0.12 & 0.12 \\
\hline E-15 & ...... & $0-1$ & 1.18 & 0.39 & 0.33 \\
\hline $\mathrm{E}-18$ & $\ldots$ & $0-1$ & 2.84 & 0.52 & 0.18 \\
\hline E-20 & $\ldots$ & $0-1$ & 3.04 & 0.85 & 0.28 \\
\hline E-21 & $\ldots$ & $0-1$ & 1.02 & 1.15 & 1.13 \\
\hline E-22 & . & $0-1$ & 2.44 & 0.47 & 0.19 \\
\hline E-25 & $\ldots$ & $0-1$ & 1.22 & 2.62 & 2.15 \\
\hline E-26 & ...... & $0-1$ & 1.19 & 0.82 & 0.69 \\
\hline E-28 & . . . & $0-1$ & 1.21 & 0.53 & 0.44 \\
\hline E-29 & . & $0-1$ & 1.33 & 0.80 & 0.66 \\
\hline $\mathrm{E}-\mathbf{3 0}$ & $\ldots$ & $0-1$ & 1.44 & 0.69 & 0.48 \\
\hline E-31 & . . . . . & $0-1$ & 1.76 & 1.45 & 0.82 \\
\hline E-32 & $\ldots$ & $0-1$ & 0.43 & 0.01 & 0.02 \\
\hline E-33 & . . . . . . & $0-1$ & 1.98 & 0.18 & 0.09 \\
\hline E-34 & & $0-1$ & 1.60 & 0.32 & 0.20 \\
\hline
\end{tabular}

TABle 14.-Continued

\begin{tabular}{|c|c|c|c|c|c|}
\hline & $\begin{array}{l}\text { ore } \\
\text { vo. }\end{array}$ & $\begin{array}{c}\text { Interval } \\
(\mathrm{cm})\end{array}$ & $\begin{array}{c}\mathrm{Fe} \\
\text { (weight } \\
\text { percent) }\end{array}$ & $\begin{array}{c}\text { Mn } \\
\text { (weight } \\
\text { percent) }\end{array}$ & $\mathrm{Mn} / \mathrm{Fe}$ \\
\hline E-35 & . . . . _ _ & $0-1$ & 1.19 & 0.28 & 0.23 \\
\hline E-36 & & $0-1$ & 1.36 & 0.24 & 0.18 \\
\hline $\mathrm{N}-1$ & & $0-3$ & 1.30 & 2.25 & 1.73 \\
\hline $\mathrm{N}-12$ & - & $0-7.5$ & 1.32 & 1.90 & 1.44 \\
\hline $\mathrm{N}-13$ & _. . . _ _ & $0-12.5$ & 1.40 & 2.25 & 1.61 \\
\hline $\mathrm{N}-23$ & . . . . & $0-7$ & 1.40 & 3.85 & 2.75 \\
\hline $\mathrm{N}-28$ & . . . . . . . & $0-12$ & 1.70 & 1.65 & 0.97 \\
\hline N-29 & . . . . . . & $0-7$ & 1.90 & 0.68 & 0.36 \\
\hline $\mathrm{N}-41$ & - - - - - & $0-11$ & 2.05 & 0.77 & 0.38 \\
\hline $\mathrm{N}-61$ & & $0-2$ & 1.32 & 0.20 & 0.15 \\
\hline N-77 & $\ldots$ & $0-3$ & 2.00 & 0.15 & 0.08 \\
\hline N-101 & . . . & $0-1$ & 1.23 & 0.33 & 0.27 \\
\hline $\mathrm{N}-102$ & - . - . . & $0-1$ & 0.83 & 0.17 & 0.20 \\
\hline N-107 & $\ldots$ & $0-1$ & 0.90 & 0.18 & 0.20 \\
\hline N-108 & & $0-1$ & 1.26 & 0.30 & 0.24 \\
\hline N-109 & $\ldots$ & $\left({ }^{1}\right)$ & 0.41 & 0.11 & 0.27 \\
\hline $\mathrm{N}-110$ & & $0-1$ & 0.82 & 0.17 & 0.21 \\
\hline $\mathrm{N}-112$ & $\ldots . .$. & $0-2$ & 0.64 & 0.10 & 0.16 \\
\hline$N-113$ & $\ldots \ldots$ & $0-3$ & 1.42 & 0.48 & 0.34 \\
\hline $\mathrm{N}-114$ & $\ldots$ & $0-3$ & 1.22 & 0.28 & 0.23 \\
\hline N-115 & $\ldots$ & $0-3$ & 0.99 & 0.30 & 0.30 \\
\hline $\mathrm{N}-116$ & $\ldots$ & $0-1$ & 1.88 & 0.21 & 0.11 \\
\hline $\mathrm{N}-117$ & $\ldots$ & $0-3$ & 1.06 & 0.28 & 0.26 \\
\hline $\mathrm{N}-118$ & - _. . . & $0-3$ & 1.11 & 0.26 & 0.23 \\
\hline $\mathrm{N}-122$ & $\ldots$ & $0-1$ & 1.00 & 0.22 & 0.22 \\
\hline N-123 & . . . - . & $0-1$ & 0.87 & 0.20 & 0.23 \\
\hline $\mathrm{N}-124$ & $\ldots$ & $0-1$ & 1.20 & 0.32 & 0.27 \\
\hline $\mathrm{N}-125$ & $\ldots$ & $0-1$ & 1.70 & 0.20 & 0.12 \\
\hline $\mathrm{N}-126$ & - . . - & $0-1$ & 1.78 & 0.50 & 0.28 \\
\hline $\mathrm{N}-131$ & ..... & $0-1$ & 1.18 & 0.18 & 0.15 \\
\hline $\mathrm{N}-134$ & & $0-2.5$ & 0.52 & 0.14 & 0.27 \\
\hline $\mathrm{N}-135$ & ...... & $0-1$ & 1.24 & 0.60 & 0.48 \\
\hline $\mathrm{N}-136$ & & $0-3$ & 1.19 & 0.30 & 0.25 \\
\hline N-137 & $\ldots$ & $0-3$ & 1.04 & 0.24 & 0.23 \\
\hline $\mathrm{N}-139$ & $\ldots \ldots$ & $0-2$ & 0.97 & 0.10 & 0.10 \\
\hline $\mathrm{N}-141$ & $\ldots$ & $\left({ }^{1}\right)$ & 1.19 & 0.38 & 0.32 \\
\hline $\mathrm{N}-142$ & . . . . & $0-3$ & 1.62 & 0.40 & 0.25 \\
\hline $\mathrm{N}-143$ & $\ldots . .$. & $0-2$ & 1.97 & 0.24 & 0.12 \\
\hline $\mathrm{N}-144$ & $\ldots \ldots$ & $0-4$ & 1.19 & 0.35 & 0.29 \\
\hline $\mathrm{N}-147$ & $\ldots \ldots$ & $0-4$ & 1.34 & 0.65 & 0.48 \\
\hline $\mathrm{N}-148$ & - . . . & $0-3$ & 1.01 & 0.36 & 0.36 \\
\hline $\mathrm{N}-149$ & - . - & $0-3$ & 1.14 & 0.30 & 0.26 \\
\hline $\mathrm{N}-151$ & . . . - & $\left({ }^{1}\right)$ & 0.94 & 0.22 & 0.23 \\
\hline $\mathrm{N}-152$ & ...... & $0-3$ & 1.35 & 0.30 & 0.22 \\
\hline $\mathrm{N}-153$ & $\ldots$ & $\left({ }^{1}\right)$ & 0.58 & 0.07 & 0.12 \\
\hline N-154 & $\ldots \ldots$ & $0-2$ & 1.91 & 0.72 & 0.38 \\
\hline N-155 & - . - _ & $0-3$ & 1.42 & 0.28 & 0.20 \\
\hline $\mathrm{N}-156$ & - . . _ & $0-4$ & 0.90 & 0.31 & 0.34 \\
\hline $\mathrm{N}-157$ & . . . . & $\left({ }^{1}\right)$ & 1.42 & 0.24 & 0.17 \\
\hline
\end{tabular}

${ }^{3}$ Grab. 
TABLE 15.-HC-extractable iron and manganese in surface sediments of southwestern Kara Sea (from Gorshkova, 1957)

\begin{tabular}{|c|c|c|c|c|c|c|}
\hline & $\begin{array}{l}\text { Station } \\
\text { No. }\end{array}$ & $\begin{array}{l}\text { Depth } \\
(\mathrm{m})\end{array}$ & $\underset{(\mathrm{cm})}{\text { Interval }}$ & $\mathrm{Mn}_{\mathrm{n}}$ & $\mathrm{Fe}$ & $\mathrm{Mn} / \mathrm{Fe}$ \\
\hline 1 & $\ldots$ & 104 & $0-4$ & 0.08 & 4.91 & 0.02 \\
\hline 4 & $\ldots$ & 158 & $\left({ }^{1}\right)$ & 1.57 & 9.35 & 0.17 \\
\hline 5 & - . - . & 145 & $0-5$ & 0.87 & 6.88 & 0.13 \\
\hline 6 & - - - - - & 62 & $\left({ }^{1}\right)$ & 0.13 & 2.31 & 0.06 \\
\hline 7 & - - - - & 62 & $\left({ }^{1}\right)$ & 0.36 & 3.99 & 0.09 \\
\hline 8 & $\ldots$ & 114 & $0-2$ & 0.62 & 4.74 & 0.13 \\
\hline 9 & $\ldots$ & 130 & $0-3$ & 0.29 & 4.00 & 0.07 \\
\hline 10 & ... . - - & 145 & $0-5$ & 0.27 & 3.89 & 0.07 \\
\hline 11 & $\ldots-\ldots$ & 200 & $0-4$ & 0.19 & 5.85 & 0.03 \\
\hline 13 & $\ldots \ldots$ & 280 & $\left({ }^{1}\right)$ & 0.18 & 3.09 & 0.06 \\
\hline 14 & - - . - . & 72 & $0-5$ & 0.13 & 2.04 & 0.06 \\
\hline 15 & $\ldots$ & 170 & $0-10$ & 0.71 & 4.19 & 0.17 \\
\hline 16 & $\ldots$ & 104 & $\left(^{1}\right)$ & 0.32 & 3.26 & 0.10 \\
\hline 17 & - . . . . - & 147 & $0-2$ & 0.47 & 4.21 & 0.11 \\
\hline 18 & $\ldots$ & 75 & $0-2$ & 0.28 & 2.82 & 0.10 \\
\hline 19 & . . - . & 48 & $\left({ }^{1}\right)$ & 0.24 & 0.27 & 0.09 \\
\hline 22 & - . . - _ & 28 & $\left({ }^{1}\right)$ & 0.04 & 1.44 & 0.03 \\
\hline 23 & $\ldots$ & 31 & $0-3$ & 0.16 & 6.63 & 0.02 \\
\hline 24 & $\ldots \ldots$ & 37 & $0-5$ & 0.07 & 5.47 & 0.01 \\
\hline 30 & $\ldots$ & 370 & $0-3$ & 0.93 & 9.10 & 0.10 \\
\hline 31 & - - . - . & 230 & $1-5$ & 0.47 & 5.24 & 0.09 \\
\hline 34 & $\ldots \ldots$ & 70 & $1-4$ & 0.27 & 3.47 & 0.08 \\
\hline 35 & - . - - - & 395 & $0-5$ & 0.71 & 5.04 & 0.14 \\
\hline 37 & $\ldots \ldots$ & 59 & $0-3$ & 0.06 & 1.89 & 0.03 \\
\hline 38 & $-\ldots$. & 75 & $0-2$ & 0.06 & 2.86 & 0.02 \\
\hline 40 & $\ldots \ldots$ & 32 & $\left({ }^{1}\right)$ & 0.03 & 2.18 & 0.01 \\
\hline 41 & $\ldots \ldots$ & 150 & $0-3$ & 1.44 & 5.25 & 0.27 \\
\hline 42 & - . . - . & 42 & $1-3$ & 0.21 & 3.40 & 0.06 \\
\hline 43 & $\ldots \ldots$ & 28 & $0-5$ & 0.04 & 2.24 & 0.02 \\
\hline 44 & $\ldots . .$. & 215 & $0-2$ & 1.31 & 4.84 & 0.27 \\
\hline 45 & $\ldots \ldots$ & 75 & & 0.04 & 2.53 & 0.02 \\
\hline
\end{tabular}

${ }^{1}$ Grab. 


$532 \cdot A A$ 

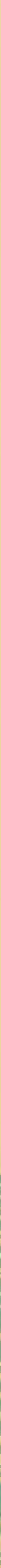